\title{
Pain Assessment-Can it be Done with a Computerised System? A Systematic Review and Meta-Analysis
}

\author{
Nuno Pombo 1,2,3,*, Nuno Garcia ${ }^{1,2,3}$, Kouamana Bousson ${ }^{4}$, Susanna Spinsante 5 \\ and Ivan Chorbev ${ }^{6}$ \\ 1 Instituto de Telecomunicações (Telecommunications Institute), University of Beira Interior, \\ Covilhã 6200-001, Portugal; ngarcia@di.ubi.pt \\ 2 Department of Informatics, University of Beira Interior, Covilhã 6200-001, Portugal \\ 3 ALLab-Assisted Living Computing and Telecommunications Laboratory, University of Beira Interior, \\ Covilhã 6200-001, Portugal \\ 4 Department of Aerospace Sciences, University of Beira Interior, Covilhã 6200-001, Portugal; bousson@ubi.pt \\ 5 Dipartimento di Ingegneria dell'Informazione, Università Politecnica delle Marche, Ancona 60121, Italy; \\ s.spinsante@univpm.it \\ 6 Faculty of Computer Science and Engineering, Ss. Cyril and Methodius University Skopje, Skopje 1000, \\ Macedonia; ivan.chorbev@finki.ukim.mk \\ * Correspondence: ngpombo@ubi.pt; Tel.: +351-275-319-700
}

Academic Editor: Peter Bath

Received: 10 February 2016; Accepted: 7 April 2016; Published: 13 April 2016

\begin{abstract}
Background: Mobile and web technologies are becoming increasingly used to support the treatment of chronic pain conditions. However, the subjectivity of pain perception makes its management and evaluation very difficult. Pain treatment requires a multi-dimensional approach (e.g., sensory, affective, cognitive) whence the evidence of technology effects across dimensions is lacking. This study aims to describe computerised monitoring systems and to suggest a methodology, based on statistical analysis, to evaluate their effects on pain assessment. Methods: We conducted a review of the English-language literature about computerised systems related to chronic pain complaints that included data collected via mobile devices or Internet, published since 2000 in three relevant bibliographical databases such as BioMed Central, PubMed Central and ScienceDirect. The extracted data include: objective and duration of the study, age and condition of the participants, and type of collected information (e.g., questionnaires, scales). Results: Sixty-two studies were included, encompassing 13,338 participants. A total of 50 (81\%) studies related to mobile systems, and $12(19 \%)$ related to web-based systems. Technology and pen-and-paper approaches presented equivalent outcomes related with pain intensity. Conclusions: The adoption of technology was revealed as accurate and feasible as pen-and-paper methods. The proposed assessment model based on data fusion combined with a qualitative assessment method was revealed to be suitable. Data integration raises several concerns and challenges to the design, development and application of monitoring systems applied to pain.
\end{abstract}

Keywords: mhealth; pain diaries; pain scales; pain assessment; chronic pain

\section{Introduction}

Chronic pain accounts for billions of dollars in annual medical expenditures [1]; in addition to that, the resulting decreased workers' productivity contributes to indirect costs [2-4], and the loss of quality of life has to be mentioned as a critical related effect. As chronic pain persists over a long period of time [5], its management results expensive due to the need of long-term rehabilitation and 
multi-disciplinary treatments [6]. In fact, the chronic condition of pain is determined by an arbitrary interval which may vary between twelve weeks, and six months [5]. However, it's hard to come up with an immediate and precise assessment that leads to the right treatments, avoiding inadequately assessed and undertreated cases [7,8]. Firstly, pain is a highly subjective experience for each individual [9]. Secondly, due to its duration, the assessment is often accomplished at the patient's home, and this represents a challenge for the accuracy of the treatment and the cost-effectiveness of the monitoring. Therefore, as self-report is considered the most accurate pain assessment method [10,11], patients should be asked to periodically rate their pain severity and related symptoms. Unsurprisingly, in the last few years, handheld devices and Internet-delivery treatment (IdT) methods were increasingly used to enable chronic pain monitoring. These systems were used for many different purposes [12], including education, reminders, feedback (in both directions between healthcare professionals and patients), and disease control.

The ubiquity of mobile devices and the Internet raised the paradigm of the new care model based increasingly more on contacts rather than visits [13]. In fact, the ability to interact with the system anywhere and anytime thoroughly changes the coordinates of time and place, and offers invaluable opportunities for new approached to healthcare delivery. Moreover, mobile devices have shown significant advances in storage capacity, battery efficiency, portability [14] and the ability to access internet-based resources [15], therefore increasing their suitability for use in healthcare systems. The adoption of technology has allowed the development of electronic pain diaries (ED) as a computerised version of paper pain diaries (PD). These systems enable patients either to report complaints close in time to the event causingpain, called ecological momentary assessment (EMA), or to address retrospective pain, that consists in pain recall over some period of time. Rather than an isolated value, pain results from multiple aspects [16-20], such as sensory (e.g., location, intensity), affective (e.g., depression, anxiety) and cognitive (e.g., quality of life) ones. For this reason, chronic pain patients are invited to answer many questionnaires and scores (e.g., McGill Pain Questionnaire, Visual Analogue Scale), and/or to adopt specific behaviours as a way to treat their pain in all its dimensions. For example, the monitoring program may include self-monitoring of pain, adherence to prescribed medications, regular exercise, and weight control. In summary then, the monitoring of chronic pain patients leads to many challenges across a range of topics such as technology (e.g., to collect and send data), clinical settings (e.g., duration of treatment, momentary pain or recall pain), and multi-dimensional pain assessment (e.g., questionnaires, scales).

The aims of this study are to describe ED implemented through mobile and web-based systems applied to chronic pain monitoring, and to determine the benefits obtained from adopting these technologies, in comparison to traditional pen-and-paper methods. This is carried out by means of an extensive review of the English-language literature about computerised systems related to chronic pain complaints.

\section{Materials and Methods}

\subsection{Research Questions}

The primary question in this review was (RQ1) Can ED replace PD for patients' monitoring? The secondary questions were (RQ2) which ubiquitous systems have been used in the monitoring of chronic pain patients? and (RQ3) which data (e.g., questionnaires and scales) are collected?

\subsection{Inclusion and Exclusion Criteria}

Studies were included in this review when they met the following criteria: (1) they dealt with computerised systems related to chronic pain complaints, (2) they included data about pain assessment, namely pain intensity; and (3) they were conducted using electronic means that included mobile devices (e.g., smartphone, Personnal Digital Assistant (PDA), tablet Personnal Computer) or web-based forms; (4) preliminary or definitive results were presented; and (5) they were written in English. These criteria 
were also applied to studies obtained from reference tracking. Reviews, study protocols, and researches where data acquisition relied exclusively on e-mails or chats were excluded. There were no age or disease restrictions: participants could be either adults or children, they might comprise chronic pain patients or healthy individuals with pain complaints.

\subsection{Search Strategy}

The team conducted a systematic search over the following electronic databases: BioMed Central, Pubmed Central, and ScienceDirect. Only the studies published from 2000 up until 30 June 2012 meeting the inclusion criteria were included. Every study was independently evaluated by two reviewers (Nuno Pombo and Nuno Garcia) and its suitability determined with the agreement of both parties. A third reviewer was considered to adjudicate on differences of opinion, but it was not required because a consensus was reached. The studies were also examined to identify and isolate clusters reporting the same data, so as to avoid the risk of bias [21].

\subsection{Extraction of Study Characteristics}

The data extracted from the studies, were tabulated (see Appendix A1) and grouped into mobile and web-based systems. For each study, details about year of publication, age of studied population (median and standard deviation (SD)), and number of participants were reported. The data managed (collected and/or complementary) by the system were grouped into three categories: pre-treatment (data obtained during the recruitment of participants were excluded), treatment and post-treatment (also includes follow up). However, data related to intervention quality and satisfaction assessment were omitted from this review. Finally, the meta-analysis included studies comprising randomised controlled trials (RCTs) that evaluated the usage of ED or IdTs and presented pre- and post-treatment comparisons. A mathematical model was used (see Section 2.7.1) to determine the effect of technology in the monitoring of pain. Firstly, the pain outcomes obtained in the RCTs' groups (intervention and control) were converted to a 0-100 scale. Secondly, a qualitative assessment (see Section 2.7.2) was performed to build an oriented analysis on pain intensity.

\subsection{Quality Assessment}

The methodological quality of all the studies was independently assessed by the two reviewers using a list of 10 criteria, which was formulated for the purpose of this study (see Appendix A2). Each criterion was rated as either poor/absent $(=0)$, reasonable $(=1)$, or good $(=2)$. Items scores were summed to obtain a total study quality score (range 0-20). As shown in Table A1, the quality sum scores were used to classify studies into two groups, above or below an average quality threshold.

\subsection{Risk of Bias Assessment}

Two reviewers (Nuno Pombo and Kouamana Bousson) independently assessed the risk of bias of each RCT included in the meta-analysis (see Table A2), using the Cochrane Collaboration's risk of bias tool [22]. Distinct domains were evaluated, such as: the method used to generate and to conceal the allocation sequence, the blinding of participants, personnel and outcome assessors, incomplete outcome data, selective outcome reporting and other sources of bias.

\subsection{Mathematical Analysis}

\subsubsection{Statistical Data Fusion}

The mathematical model is based on the data fusion methods described in [23-25] and summarized below.

Let us consider $n$ sets of data samples, each of which has a Gaussian distribution $\mathrm{N}\left(\bar{x}_{i}, \sigma_{i}\right)$, where $\bar{x}_{i}$ and $\sigma_{i}$ are respectively the mean (or mathematical expectation) and the standard deviation of 
samples in the set $i$. Then, the probability distribution of the aggregated set is again Gaussian with a mean $\bar{x}_{i}$ and a standard deviation $\sigma$ computed as:

$$
\bar{x}=\sum_{i=1}^{n} a_{i} x_{i}=\alpha \sum_{i=1}^{n} \frac{x_{i}}{\sigma_{i}^{2}}
$$

where $a_{i}$ is defined by:

$$
\begin{gathered}
a_{i}=\frac{1}{\sigma_{i}^{2}} \alpha, i=1, \ldots, n \\
\text { and } \alpha=\left(\frac{1}{\sigma_{1}^{2}}+\frac{1}{\sigma_{2}^{2}}+\ldots+\frac{1}{\sigma_{N}^{2}}\right)^{-1} \\
\text { and } \sigma^{2}=\sum_{i=1}^{N} a_{i}^{2} \sigma_{i}^{2}
\end{gathered}
$$

\subsubsection{Qualitative Analysis}

The mean and the standard deviation, computed as described in the last section, are used for the qualitative analysis method, that we proposed below, which aims to produce a more accurate outcome. Let us consider:

$\sigma_{T}:$ standard deviation of technology outcome;

$\sigma_{P}$ : standard deviation of pen-and-paper outcome;

$\bar{x}_{T}$ : mathematical expectation of technology outcome;

$\bar{x}_{P}$ : mathematical expectation of pen-and-paper outcome;

Consider furthermore the following conditions:

Condition (P): $\bar{x}_{P} \in\left(\bar{x}_{T}-\sigma_{T}, \bar{x}_{T}+\sigma_{T}\right)$ or $\bar{x}_{T} \in\left(\bar{x}_{P}-\sigma_{P}, \bar{x}_{P}+\sigma_{P}\right)$ for instance as shown in Figure 1 where $\bar{x}_{T}=3, \bar{x}_{P}=2, \sigma_{T}=1.2, \sigma_{P}=0.6$

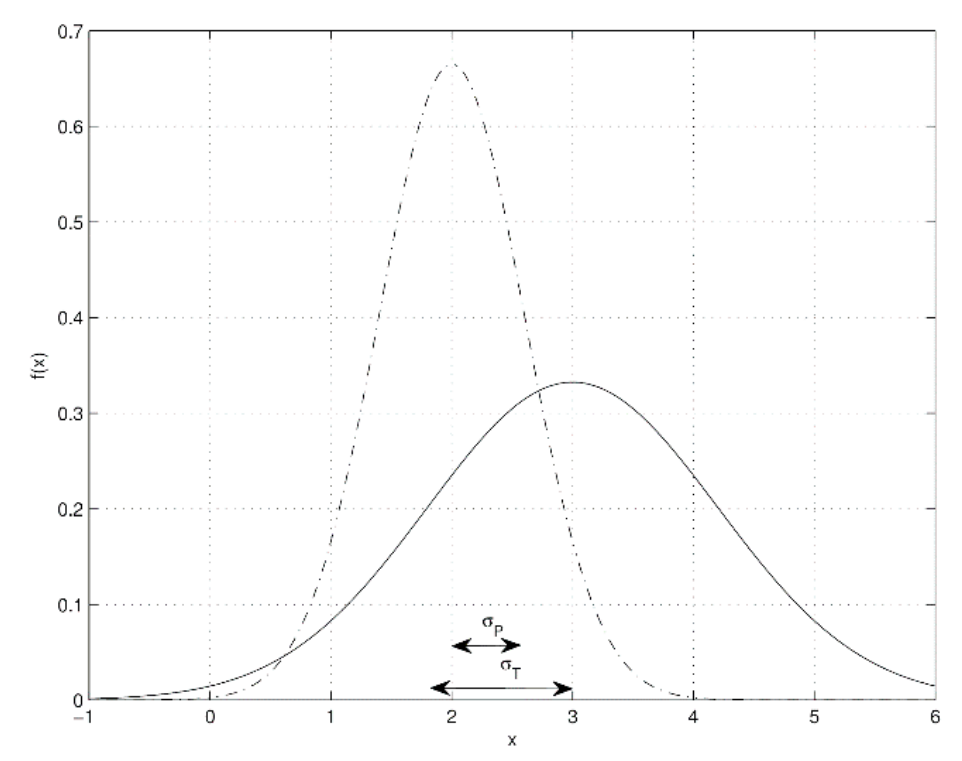

Figure 1. Example of a distribution curve when technology and pen-and-paper are qualitatively equivalent.

The opposite condition is presented in Figure 2 with $\bar{x}_{T}=3, \bar{x}_{P}=1, \sigma_{T}=0.9, \sigma_{P}=0.8$. The rationale of condition $(\mathrm{P})$ is that since the standard deviation $\sigma$ is the average magnitude of the sample dispersion with respect to its mean value $\bar{x}$ (mathematical expectation), any value $x$ that is 
located at a distance from $\bar{x}$ less than the standard deviation (that is, $|x-\bar{x}|<\sigma$ ) may be considered as qualitatively equal to $\bar{x}$. Using condition (P) described above, a qualitative analysis is performed to clarify which one among technology and pen-and-paper approach provides the best way to get fair results in pain monitoring.

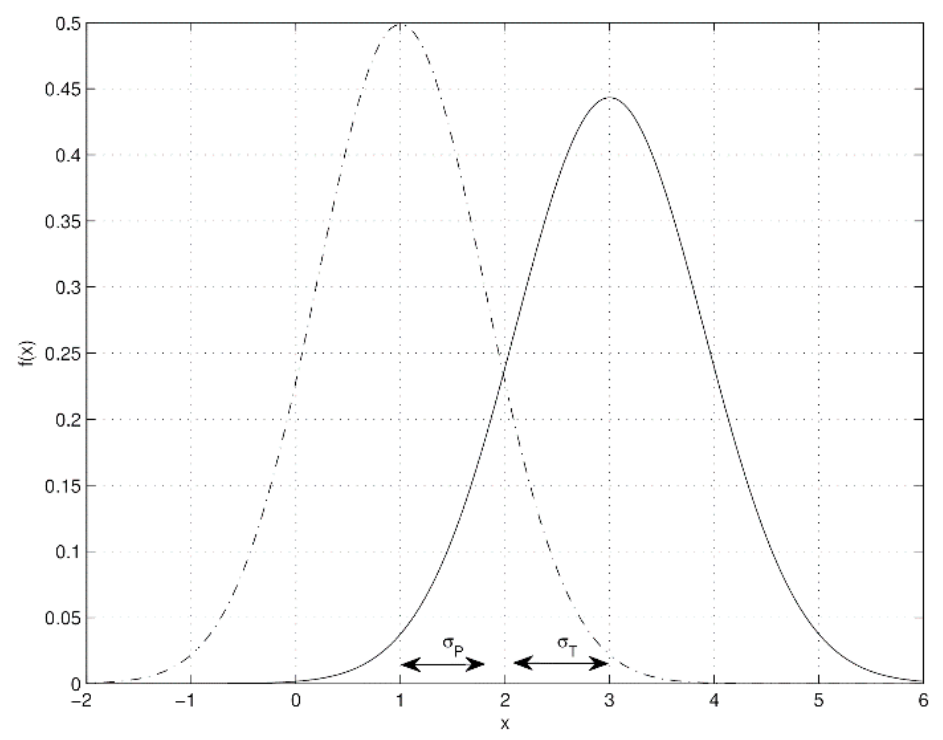

Figure 2. Example of a distribution curve when technology and pen-and-paper are qualitatively different.

Case 1: when the lower mean value (mathematical expectation) implies better results:

If condition $(\mathrm{P})$ is verified, then using technology or pen-and-paper gives rise to the same conclusion, even though the mean values may be different; else if $\left(\bar{x}_{T}<\bar{x}_{P}\right)$ then technology provides better results than pen-and-paper; else pen-and-paper provides better results than technology.

Case 2: when the higher mean value (mathematical expectation) implies better results:

If condition $(\mathrm{P})$ is verified, then using technology or pen-and-paper gives rise to the same conclusion, even though the mean values may be different; else if $\left(\bar{x}_{T}>\bar{x}_{P}\right)$ then technology provides better results than pen-and-paper; else pen-and-paper provides better results than technology.

\subsubsection{Considerations for the Analysis}

Several studies were excluded from this analysis due to the absence of comparisons between pre-treatment and post-treatment outcomes [26-33], or the absence of technology validation purposes [34]. The remaining sixteen unique studies were assessed in terms of risk of bias (see Appendix A3). Three studies [35-37] were appraised to be at lowest risk of bias, as they met every criterion except the blinding of participants, personnel and outcome assessors. In fact, none of the included RCTs met this criterion. The lack of information and explanation for attrition and missing data was observed, whereas all studies clearly reported the different outcomes. These outcomes were used to implement statistical analysis across the included RCTs. During the analysis, one study was excluded due to the inexistence of SD in the reported data [38]. In addition, several studies were partially excluded due to high SD in some outcomes (a.k.a. outliers) [39,40], or due to unfeasible conversion from t-scores to a continuous scale [35]. Instead of a single analysis of the studies, the pre- and post-treatment data obtained from intervention groups and control groups across the different RCTs were combined using data fusion methods [23-25], and compared to produce a more accurate conclusion. Thus, as shown in Table 1, the adoption of technology related with pain intensity was assessed. 
Table 1. Comparison between pen-and-paper, and mobile and web technology using pre and post treatment results by study and overall.

\begin{tabular}{|c|c|c|c|c|c|c|c|c|c|c|}
\hline \multicolumn{11}{|c|}{ Pain intensity } \\
\hline \multirow[b]{2}{*}{ Study } & \multirow[b]{2}{*}{ Variable } & \multicolumn{2}{|c|}{ Technology } & \multicolumn{2}{|c|}{ Pen and Paper } & \multicolumn{2}{|l|}{ Technology } & \multicolumn{2}{|c|}{ Pen and Paper } & \multirow[b]{2}{*}{ Favourable To } \\
\hline & & $\begin{array}{l}\text { Pre Treatment } \\
\text { Value (SD) }\end{array}$ & $\begin{array}{l}\text { Post Treatment } \\
\text { Value (SD) }\end{array}$ & $\begin{array}{c}\text { Pre Treatment } \\
\text { Value (SD) }\end{array}$ & $\begin{array}{l}\text { Post Treatment } \\
\text { Value (SD) }\end{array}$ & Aggregated Value & SD & Aggregated Value & SD & \\
\hline Berman [41] & BPI (mean) & $52(19.40)$ & $45.60(18.30)$ & $54.30(17.40)$ & 47.30 (18.40) & 48.61 & 13.31 & 51 & 12.64 & Technology \\
\hline \multirow{2}{*}{ Buhrman [36] } & Pain (mean) & $37.40(18.20)$ & $34.30(16.80)$ & $44.4(14.20)$ & $39.6(16.30)$ & 35.73 & 12.34 & 42.33 & 10.71 & Technology \\
\hline & MP-pa in severity & $63.33(31.67)$ & $40(18.33)$ & 83.33 (28.33) & $53.33(13.33)$ & 45.86 & 15.87 & 58.77 & 12.06 & Technology \\
\hline Devineni [42] & Headache pain & $31.80(17)$ & $18.60(13)$ & $35.50(15.50)$ & $30.60(14.70)$ & 23.47 & 10.33 & 32.92 & 10.67 & Technology \\
\hline Hicks [43] & Pain (mean) & $48(13)$ & $34(24)$ & $43(16)$ & $47(22)$ & 44.82 & 11.43 & 44.38 & 12.94 & Pen-and-Paper \\
\hline Litt [44] & MPI (mean) & $43.83(21)$ & $20.50(16.33)$ & 35.17 (14.33) & $25(22.67)$ & 29.29 & 12.89 & 32.26 & 12.11 & Technology \\
\hline Ljótsson [45] & Pain & $65(42.50)$ & $35(37.50)$ & $60(37.50)$ & $60(40)$ & 48.13 & 28.12 & 60 & 27.36 & Technology \\
\hline Lorig [39] & Pain & $65.30(22.70)$ & $58.60(24.40)$ & $63.70(22.20)$ & $63.40(23.10)$ & 62.19 & 16.62 & 63.56 & 16.01 & Technology \\
\hline \multirow{2}{*}{ Palermo [37] } & Pain & $54.50(22.50)$ & $35.40(24.20)$ & $51.70(16.50)$ & $47.60(18.40)$ & 45.64 & 16.48 & 49.87 & 12.28 & Technology \\
\hline & Retrospective pain & $66.30(18.70)$ & $49.60(21.80)$ & $61.60(18.40)$ & $54.50(20.40)$ & 59.22 & 14.19 & 58.42 & 13.66 & Pen-and-Paper \\
\hline Ruehlman [46] & PCP-S-pain severity & 76.47 (9.72) & $71.10(12.94)$ & 74.78 (10.91) & 71.66 (13.28) & 74.53 & 7.77 & 73.52 & 8.43 & Pen-and-Paper \\
\hline Turner [47] & Pain (mean) & $43(22)$ & $39(24)$ & $43(19)$ & $40(22)$ & 41.17 & 16.22 & 41.72 & 14.38 & Technology \\
\hline Williams [48] & BPI-pain severity & $51(14)$ & $43(16)$ & 49 (14) & 49 (15) & 47.53 & 10.54 & 49 & 10.23 & Technology \\
\hline \multirow{2}{*}{ Fusion } & value & $55.90(4.80)$ & $40.57(5.08)$ & $52.65(4.56)$ & $49.02(4.94)$ & 48.67 & 3.49 & 50.98 & 3.35 & Equivalent \\
\hline & alpha & 23.04 & 25.82 & 20.79 & 24.38 & & & & & \\
\hline
\end{tabular}




\section{Results}

As illustrated in Figure 3, 490 unique citations were identified, of which 378 were excluded as a result of screening, in terms of title, abstract, and keywords. The remaining 112 papers were full text evaluated, which resulted in the exclusion of 63 papers that did not match the defined criteria. Furthermore, the reference tracking allowed for the inclusion of 13 additional papers. In summary then, our review examined 62 papers, representing 55 unique studies, due to the fact that studies reporting the same data were clustered to avoid risk of bias.

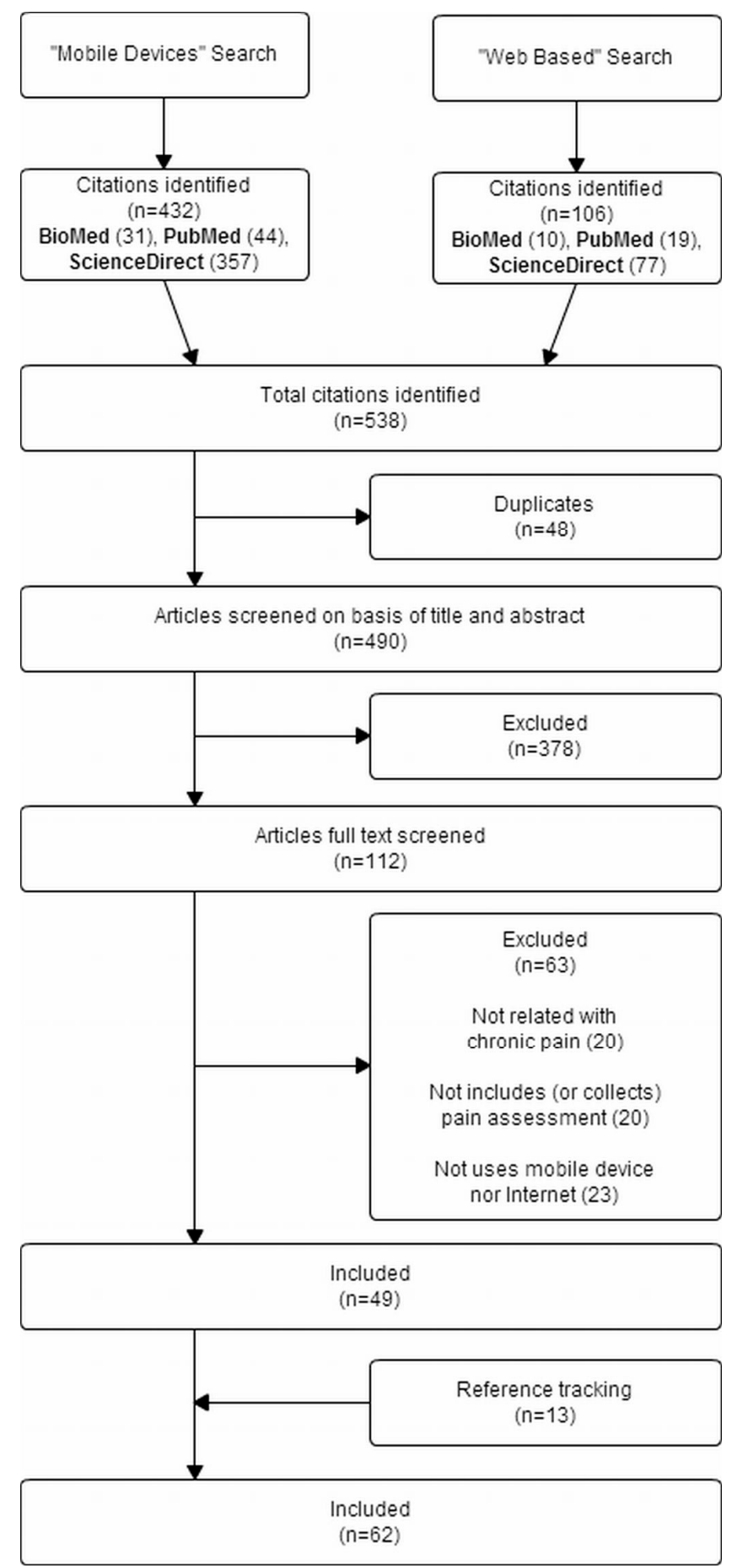

Figure 3. Selected studies. 
The included studies encompass a total of 13,338 participants distributed by 43 studies (78\%) related to mobile systems, and $12(22 \%)$ studies dealing with web-based systems. Eighty-one percent of mobile systems (35 studies) were designed to enable usage in patients' home whereas the remaining eight studies limited their use within hospital facilities. The data were collected at intervals or during the clinical visit or at the end of the study, and transmitted to the system database by different channels, such as: Internet, SMS, or cable. Web-based systems were reported in 12 studies varying between online questionnaires and cognitive-behavioural therapy (CBT). Moreover, 10 studies (83\%) used phone calls, SMS or emails as a complement of the IdT. This methodology aims to remind patients to collect data, support system handling, and to establish contact between healthcare professionals and patients.

Moreover, 16 out of the 55 studies (29\%) included in this review were published before or during 2006, and among the remaining 39 studies, 27 studies were published between the beginning of 2008 and the end of 2010. Thirty-two studies (58\%) included complementary data, obtained outside the system in at least one of the following phases: pre-treatment (28 studies), treatment (8 studies) or post-treatment (16 studies).

The most representative objective was validating the IdT (12 studies, $22 \%$ ), the assessment of ED (12 studies), the comparison between ED and PD (nine studies), the comparison between recalled pain and EMA (six studies), and the evaluation of medication in treatment of patients suffering from pain (three studies). Eight studies reported the correlation of several pain conditions, namely: physical activity, relationship, emotional distress, fear, and sleep.

The CBT was presented in 19 studies, among which seven were related to mobile systems. The remaining 12 studies presented CBT as a support of IdT, and included tailored exercises according to participants' symptoms, multimedia content, information and lessons about physical, cognitive, behavioural and motivational topics. The main principles of CBT for chronic pain management are based on helping the patient understand how much pain is experienced, coping-skills training, and cognitive restructuring affected by cognition and behaviour [49].

\subsection{Mobile Systems}

Forty-three studies were related to mobile systems, out of which $35(81 \%)$ were designed to allow their usage in patients homes during at least one phase of the intervention (pre/post-treatment, treatment). The remaining eight studies were limited to the use of the proposed system in hospital facilities during patients' visits and thereby only comparisons among sporadic records collected during the treatment period were provided. Meanwhile, 19 studies presented transmission of data to a remote server immediately after its edition. Three studies did not report this process, whereas 21 studies reported elapsed time between the editing and the subsequent delivery. Thus, data were collected at intervals, or during the clinic visit, or at the end of the study. Internet was the preferred channel for sending data (14 studies), followed by uploading through personal computer (nine studies), and SMS (three studies). Data transmission after its edition may allow real-time access to physicians, and therefore, clinical decisions supported by updated information on the patient's conditions. Moreover, undelayed data transmission may provide the enforcement of triggering messages and alerts according to the reported pain values. This method was highlighted by four studies and comprised a clinical session report generation, SMS alerts according to answers and warning messages about the activity patterns, displayed in PDA. Data storage in a Personal Health Record (PHR), wrist actigraphy in sleep assessment, and activity monitoring supported by a Body Area Network (BAN) were proposed in a single study respectively. Interactive voice recorder (IVR) was referred in two studies $[44,50]$. Time of intervention ranged from one clinical session to 52 weeks (one year).

\subsection{Web-Based Systems}

Web-based systems were reported in 12 studies, out of which 11 consisted in RCTs, comprising two groups of participants called: intervention group (IG) and control group (CG). The difference between 
them is that a web site was used to deliver the treatment to IG participants. At the end of intervention, participants of both groups were assessed and the IdT effects were determined. The IdT consisted of online questionnaires and/or CBT. All the articles reported positive effects and improvement in health status. With the exception of [37,39], all web-based systems used emails or phone calls jointly with Internet (83\%). Six studies adopted e-mails $[41,42,45,46,48,51]$ and three of them also performed phone calls $[45,46,48]$, to remind patients to use and/or interact with the system. In addition, emails were applied to obtain data $[40,45,46,51]$, to support the system handling [36,41], and, together with phone calls, to establish a contact between healthcare professionals and patients [36,43]. One study [40], allowed phone calls to support the system handling. Finally, [52] used SMS to remind patients to collect data. In the same study, mobile phones with Internet access were used to present a web site whereupon treatment was provided, and therefore, it has been classified as a web-based system. Time of intervention ranged from 3 to 52 weeks (one year). It should be noted that remote data transmission is not required in these systems, while it occurs in mobile monitoring applications.

\subsection{Meta-Analysis}

The qualitative and quantitative analysis (see Section 2.7) revealed that the benefits of technology and pen-and-paper are equivalent on pain intensity $(48.67 \in(50.98 \pm 3.35)$ and $50.98 \in(48.67 \pm 3.49))$, as presented in Table 1. Firstly, the proposed statistical data fusion model processes each study as a different sensor and computes the individual mean and SD, related with the processed variable (determined by the collected data from questionnaires and/or scores) in both arms of the study (pen-and-paper group and computerised system group). Secondly, the combination of these values resulted in an aggregate value. Thirdly, the fusion model computes all aggregate values and presents a final decision according to the rules defined in Section 2.7.

\section{Discussion}

Some potentials and risks related to mobile and web-based systems were evidenced from the full text evaluation of included studies. Firstly, the usage of ED produces more reliable data compared to PD. Secondly, ED and IdT result in real-time analyses and subsequent agile treatment adjustments. Thirdly, ED and IdT provide time-saving and enable cost-effective medical practices. Nevertheless, training for clinical staff is critical [53], and strongly recommended to promote standardised procedures and adherence [54]. In addition, device failures considered in system design [55], should be addressed to avoid missing values and/or prolonged data editing. It should be noticed that due to the frequent loss of mobile devices, their use to store health records implies the risk of losing data and personal information. These topics, along with the inefficient use of collected data to improve treatment effectiveness, emerged as critical limitations. This review included 19 studies related to CBT, in which the following outcomes were observed: the effectiveness for decreasing chronic pain, in line with [49,56,57], the reduction of pain related behaviours as suggested by [58,59], and a facilitated return to work, as presented by $[60,61]$. In spite of their absence in these studies, innovative CBT, such as: serious games $[62,63]$ and augmented reality $[64,65]$, seem to be promising. Serious games are the application of motivational aspects of gaming to encourage positive health behaviours [66], whereas augmented reality provides virtual environments combined with touch sensations resulting from interacting with real objects [67]. Further work is needed to understand how these technologies can aid the transformation of CBT delivery models.

The use of SMS [68] to collect data, as proposed by [69-72], and to deliver CBT, as suggested by [52], may improve treatment outcomes, due to the fact that tailoring messages to individuals may lead to effective health behaviour changes [73-75]. Only one study [76], mentioned data integration with other systems such as PHR, which suggests limitations on accessing the collected data. In addition, some mobile-based systems were designed to interact directly with patients without the presence of a healthcare professional $[77,78]$ and/or without evidence of reliability and accuracy. However, as pain is a multifaceted experience, its therapy tends to involve many healthcare professionals and different 
expertises whereby the data integration may result in the reduction of not regulated self-diagnosis [79]. Therefore, it is desirable that patient information may be obtained and delivered both easily and safely (e.g., avoidance of medical examination redundancy, faster patient profile acquisition, and permanent storage of clinical records) which raises some concerns and challenges related to security aspects such as privacy and confidentiality [80], and reliable communication methods between healthcare professionals and patients.

In line with this, cloud computing as an emerging technology that provides elastic infrastructure, and efficient resource utilization [81], appears to be a promising solution for design, development and integration of systems. This technology may enable scalable, portable, and interoperable mobile and web-based systems as to deliver clinical solutions to the patients, anytime and anywhere [82]. In addition, social media websites have been useful in the last few years to improve networking and communication [83] (e.g., Facebook, Twitter), and represent a new source of information and knowledge. Therefore, it is expected that clinical systems will advance to interact with patients via social media, so as to provide CBT, serious games, self-help, symptoms information and multimedia content. Thus, new studies should be addressed to determine the real benefits and disadvantages of treatments delivery using social media. Furthermore, complementary studies should be carefully addressed to analyse both data and patient privacy.

Finally, our meta-analysis demonstrated that the effects of technology and pen-and-paper should be obtained not only based on the comparison of the standard deviations together with the values of the mathematical expectations, but also considering the condition $(\mathrm{P})$ described in Section 2.7. In addition, the outcome of our meta-analysis is highly accurate as evidenced by the lower SD of the obtained aggregated values (resulting from the computation of the SD of all the included samples) compared with the individual SD presented in each study. In fact, we found that technology and pen-and-paper present equivalent outcomes suggesting not only that technological systems are feasible, but also there is room for improvement to produce significant effects in patients' conditions and welfare. Moreover, further studies should be promoted to determine not only the effect of technology on different dimensions of pain (e.g., anxiety, depression, catastrophizing, disability and interference) but also the side effects of the application of technology in economic, medical, educational, and social domains.

\section{Conclusions}

This review distinguished mobile and web-based systems related to chronic pain complaints. Sixty-two studies were examined and the main findings are summarised as follows:

(RQ1) The qualitative analysis model, stemming from the data fusion method, combined with a quantitative model, based on the comparison of the standard deviations together with the values of the mathematical expectations, revealed that technology is equivalent to pen-and-paper in terms of effect on pain intensity monitoring;

(RQ2) Sixty-two studies were included encompassing 13,338 participants. A total of 50 (81\%) studies related to mobile systems, and $12(19 \%)$ related to web-based systems;

(RQ3) The data extracted from the included studies, revealed the use of almost ninety different scales and questionnaires at pre/post/during treatment. The data collected comprised, among others: location, duration, and intensity of pain, consequences as the impact on quality of life, emotional and aversive aspects. This highlights the multi-dimensional nature of pain.

Despite these findings, effects of technology on practitioners and patients outcomes remain understudied, and their promise to increase self-care and accurate monitoring remains mostly untested. In addition, data integration raises several concerns and challenges to the design, development and application of monitoring systems applied to pain. 


\section{Limitations}

Some limitations of this review should be mentioned. First, only English-language publications were included. Second, the lack of technical explanations related to data acquisition, transmission and storage, restricted both analysis and extraction. Third, the null hypothesis was considered, that means, all sample data are assumed to be sufficient.

Acknowledgments: This work was supported by Fundação para a Ciência e Tecnologia (FCT) project UID/EEA/50008/2013 (Este trabalho foi suportado pelo projecto FCT UID/EEA/50008/2013). The authors would also like to acknowledge the contribution of the COST Action IC1303-AAPELE-Architectures, Algorithms and Protocols for Enhanced Living Environments. The first author would like to dedicate this study to the memory of his 8-year-old daughter, Carolina, whose determination, happiness and love inspired him.

Author Contributions: Nuno Pombo and Kouamana Bousson conceived and designed the experiments; Nuno Pombo and Nuno Garcia performed the experiments; Nuno Pombo, Kouamana Bousson, and Nuno Garcia analyzed the data; Susanna Spinsante and Ivan Chorbev contributed reagents/materials/analysis tools; Nuno Pombo wrote the paper. Nuno Garcia, Kouamana Bousson, Susanna Spinsante, and Ivan Chorbev revised the paper.

Conflicts of Interest: The authors declare no conflict of interest. The founding sponsors had no role in the design of the study; in the collection, analyses, or interpretation of data; in the writing of the manuscript, and in the decision to publish the results.

\section{Abbreviations}

The following abbreviations are used in this manuscript:

CBT Cognitive-behavioural Therapy

CG Control Group

ED Electronic pain diaries

EMA Ecological Momentary Assessment

IdT Internet-delivery treatment

IG Intervention Group

PD Paper pain diaries

PHR Personal Health Record

RCT Randomised controlled trial

SD Standard Deviation 


\section{Appendix A1}

Table A1. Studies characteristics.

\begin{tabular}{|c|c|c|c|c|c|c|}
\hline \multirow{2}{*}{ Study/Year } & \multirow{2}{*}{$\begin{array}{l}\text { Population Participants } \\
\text { (Mean Age, SD) }\end{array}$} & \multirow{2}{*}{ Patient Home } & \multicolumn{3}{|c|}{ Data } & \multirow{2}{*}{ Quality } \\
\hline & & & As a Complement to the System & Collected through the Use of System & Transmission & \\
\hline \multicolumn{7}{|c|}{ Mobile systems } \\
\hline Allen [84,85], 2009 & $157(61.7 \pm 10.6)$ & Yes & Pre: CSQ & $\begin{array}{l}\text { Pain intensity (VAS), immediately after waking, then } \\
\text { approximately every } 2 \mathrm{~h} \text { throughout the day (in order to } \\
\text { complete at least } 7 \text { pain ratings per day) and immediately } \\
\text { before going to sleep (to recall the average pain during the day) }\end{array}$ & NR & $\mathrm{L}$ \\
\hline Anatchkova [86], 2009 & 100 & No & & $\begin{array}{l}\text { Pain intensity (NRS), computer adaptive dynamic assessment } \\
\text { of The Chronic Pain Impact Item Bank [87], and SF-12, in the } \\
\text { medical appointment }\end{array}$ & NR & $\mathrm{L}$ \\
\hline Axen [69,70], 2011 & $262(44)$ & Yes & $\begin{array}{l}\text { Pre: Pain intensity (NRS), location, duration and } \\
\text { frequency, self-rated general health (5-point Likert } \\
\text { scale). EuroQoL } 5 \text { (EQ5D) } \\
\text { Post: EQ5D and self-rated general health (6-months } \\
\text { follow up) }\end{array}$ & Pain intensity (NRS), once a week using SMS & Instant & $\mathrm{L}$ \\
\hline Badr [88], 2010 & $\begin{array}{l}54 \text { patients }(49.4 \pm 10.8) \\
48 \text { partners }(51.3 \pm 11.5)\end{array}$ & Yes & & $\begin{array}{l}\text { Patients: pain intensity (NRS), mood, medication taken and } \\
\text { pain relief, } 6 \text { times per day between } 9 \text { a.m. and } 9 \text { p.m. } \\
\text { Perceptions of relationship functioning in the last assessment } \\
\text { of the day. } \\
\text { Partners: patients' pain, own mood and perceptions of } \\
\text { relationship functioning, at similar time points }\end{array}$ & Instant & $\mathrm{L}$ \\
\hline $\begin{array}{l}\text { Baron-Mahn }[89,90] \\
2009\end{array}$ & $\begin{array}{l}2094 \text { painful } \\
\text { radiculopathy } \\
(59.4 \pm 14.4) \\
1623 \text { painful diabetic } \\
\text { neuropathy }(61.9 \pm 13.0) \\
\quad 498 \text { postherpetic } \\
\text { neuralgia }(60.6 \pm 15.4)\end{array}$ & No & & $\begin{array}{l}\text { MOS-SS, PHQ, PD-Q and pain location (pinpointed in 3D } \\
\text { mannequin) in the medical appointment }\end{array}$ & Delayed & $\mathrm{L}$ \\
\hline $\begin{array}{l}\text { Broderick-Schneider } \\
\text { [50,91,92], } 2008\end{array}$ & $83(56.2 \pm 11.1)$ & Yes & $\begin{array}{l}\text { Treatment: } 10 \text { random recalls pain assessment via } \\
\text { phone interview (interactive voice recording was used) } \\
\text { Post: Pain Intensity (VAS) }\end{array}$ & $\begin{array}{l}\text { SF-36, BPI, BFI, MPQ, } 7 \text { times per day during the patients' } \\
\text { waking hours }\end{array}$ & Delayed & $\mathrm{L}$ \\
\hline Clauw [34], 2008 & $\begin{array}{l}399 \text { IG } 100 \mathrm{mg} / \text { day } \\
\quad(49.5 \pm 10.9) \\
396 \mathrm{IG} 200 \mathrm{mg} / \text { day } \\
\quad(50.4 \pm 10.6) \\
401 \mathrm{CG}(50.7 \pm 10.4)\end{array}$ & Yes & $\begin{array}{l}\text { Pre: FIQ, MASQ, MOS-SS, MDHAQ, MFI, BDI, } \\
\text { and ASEX } \\
\text { Treatment: 3, 7, } 11 \text { and } 15 \text { week visit: PGIC, SF-36, FIQ, } \\
\text { MASQ, MOS-SS, MDHAQ, MFI. BDI and ASEX only at } \\
\text { week } 15\end{array}$ & $\begin{array}{l}\text { Diary: pain intensity (VAS), } 5 \text { times per day (morning, } 3 \\
\text { during day and evening) } \\
\text { Weekly: pain, fatigue, influence of pain in self-care (VAS) }\end{array}$ & Instant & $\mathrm{H}$ \\
\hline Connelly [93], 2010 & $9(12.3 \pm 3.4)$ & Yes & & $\begin{array}{l}\text { Children: pain intensity (VAS), PANAS-C, CALQ, } 3 \text { times per } \\
\text { day (morning, afternoon, and evening) } \\
\text { Parents: PANAS, ARCS at the same time points, using a } \\
\text { separate PDA }\end{array}$ & Delayed & $\mathrm{L}$ \\
\hline
\end{tabular}


Table A1. Cont.

\begin{tabular}{|c|c|c|c|c|c|c|}
\hline \multirow{2}{*}{ Study/Year } & \multirow{2}{*}{$\begin{array}{l}\text { Population Participants } \\
\text { (Mean Age, SD) }\end{array}$} & \multirow{2}{*}{ Patient Home } & \multicolumn{3}{|c|}{ Data } & \multirow{2}{*}{ Quality } \\
\hline & & & As a Complement to the System & Collected through the Use of System & Transmission & \\
\hline Gaertner [94], 2004 & $\begin{array}{c}24(49.9 \pm 15.1) \\
\text { Crossover randomized } \\
\text { between IG and CG }\end{array}$ & Yes & & $\begin{array}{l}\text { Pain intensity (NRS), once a day and symptom assessment } \\
\text { (fatigue, nausea, dyspnea, weakness ... ), once a week }\end{array}$ & Delayed & $\mathrm{L}$ \\
\hline Ghinea [95], 2008 & $45(46.1)$ & Yes & & $\begin{array}{l}\text { Pain intensity (VAS) and location (pinpointed in 3D } \\
\text { mannequin), } 3 \text { times a day }\end{array}$ & Instant & $\mathrm{L}$ \\
\hline Giske [72], 2010 & $50(50.0 \pm 11.0)$ & Yes & $\begin{array}{l}\text { Pre: HSCL-25, FIQ } \\
\text { Post: Pain intensity (VAS) and pain location }\end{array}$ & $\begin{array}{l}\text { Pain intensity (NRS), } 5 \text { times a day between } 9 \text { a.m. and } 9 \text { p.m., } \\
\text { using SMS }\end{array}$ & Instant & $\mathrm{L}$ \\
\hline Heiberg [96], 2007 & $38(58.4 \pm 12.9)$ & Yes & & $\begin{array}{l}\text { Diary: pain intensity (VAS), fatigue, and patient global } \\
\text { evaluation of their disease, RADAI, } 4 \text { times per day } \\
\text { Weekly: MHAQ, SF-36 }\end{array}$ & Instant & $\mathrm{H}$ \\
\hline Jamison [28], 2001 & $\begin{array}{l}20 \text { IG }(42.1 \pm 5.0) \\
16 \text { CG }(43.3 \pm 9.2)\end{array}$ & Yes & $\begin{array}{l}\text { Pre: CPEQ, SCL-90 } \\
\text { Treatment: MPQ-SF (once a month). Pain reported } \\
\text { weekly by phone interview } \\
\text { Post: SCL-90 }\end{array}$ & $\begin{array}{l}\text { Pain intensity (VAS) and pain ratings of the previous } 16 \\
\text { waking hours, once a day (bedtime) }\end{array}$ & Delayed & $\mathrm{H}$ \\
\hline Jamison [97], 2002 & $24(34.4)$ & No & & Pain intensity (VAS) & Delayed & $\mathrm{L}$ \\
\hline Jamison [98], 2006 & $21(42.0 \pm 4.9)$ & Yes & $\begin{array}{l}\text { Pre: CPEQ, SF-36, MPQ-SF, SCL-90 } \\
\text { Treatment: Pain reported weekly by phone interview }\end{array}$ & Pain intensity (VAS), at least once a day & Delayed & $\mathrm{H}$ \\
\hline $\begin{array}{l}\text { Jamison-Wasan } \\
{[26,27], 2010}\end{array}$ & $\begin{array}{c}21 \mathrm{IG} \mathrm{ED}+\mathrm{CBT} \\
(47.0 \pm 7.8) \\
21 \mathrm{CG} \# 1 \mathrm{ED}(46.6 \pm 6.8) \\
20 \mathrm{CG} \# 2 \mathrm{ED}(49.6 \pm 6.8)\end{array}$ & Yes & $\begin{array}{l}\text { Pre and Post: ABC, BPI, COMM, HADS, MINI, PDI, } \\
\text { SOAPP-R } \\
\text { Post: PDUQ }\end{array}$ & $\begin{array}{l}\text { BPI, pain location once a month at clinic visit Wasan's study, } \\
\text { also includes four questions to assess craving for prescription } \\
\text { opioids over the past } 24 \mathrm{~h} \text { ( } 14 \text { days ED at patients' home) } \\
\text { CBT: Group educational sessions (e.g., opioid addiction risks } \\
\text { and medication compliance, making lifestyle changes...) and } \\
\text { individual motivational counseling (review of medication } \\
\text { adherence, support for patients' efforts, education on pain } \\
\text { management and drug misuse...) }\end{array}$ & Delayed & $\mathrm{H}$ \\
\hline Jespersen [71], 2012 & $188(44.4 \pm 9.0)$ & Yes & Pre: AMS & AMS, IPAQ, once a week using SMS & Instant & $\mathrm{H}$ \\
\hline Koroschetz [99], 2011 & $\begin{array}{l}1623 \text { painful diabetic } \\
\text { neuropathy }(61.9 \pm 13.0) \\
1434 \text { fibromyalgia } \\
(51.9 \pm 10.8)\end{array}$ & No & & $\begin{array}{l}\text { MOS-SS, PHQ, PD-Q and pain location (pinpointed in 3D } \\
\text { mannequin) in the medical appointment }\end{array}$ & Delayed & $\mathrm{L}$ \\
\hline Kvien [100], 2005 & $30(61.6)$ & No & & $\begin{array}{l}\text { Pain intensity (VAS), fatigue, and patient global evaluation of } \\
\text { their disease, RADAI, MHAQ, SF-36, at } 2 \text { medical } \\
\text { appointments }\end{array}$ & Instant & $\mathrm{L}$ \\
\hline $\begin{array}{l}\text { Lewandowski [101], } \\
\qquad 2010\end{array}$ & $\begin{array}{c}39 \text { chronic pain } \\
(15.3 \pm 1.5) \\
58 \text { healthy participants } \\
(14.7 \pm 1.8)\end{array}$ & Yes & Pre: CES-D & $\begin{array}{l}\text { Sleep quality (NRS) in the morning and pain intensity (NRS) in } \\
\text { the evening. Integrated with wrist actigraphy to monitorize } \\
\text { the sleep }\end{array}$ & Delayed & $\mathrm{L}$ \\
\hline Levin [102], 2006 & 24 & Yes & & $\begin{array}{l}\text { Pain intensity (NRS), location, duration reported via } \\
\text { automated speech telephony delivery (a.k.a automated speech } \\
\text { recognition) }\end{array}$ & Instant & $\mathrm{L}$ \\
\hline Li [103], 2010 & $60(69.0 \pm 10.0)$ & Yes & Pre and Post: MPQ-SF & MPQ-SF, 8 times per day (hourly between 2 and 9 p.m.) & Delayed & $\mathrm{H}$ \\
\hline Lind [104], 2008 & $12(67.5 \pm 7.8)$ & Yes & & Pain intensity (VAS), 3 times a day ( 8 a.m., 1 p.m., 8 p.m.) & Instant & $\mathrm{L}$ \\
\hline
\end{tabular}


Table A1. Cont.

\begin{tabular}{|c|c|c|c|c|c|c|}
\hline \multirow{2}{*}{ Study/Year } & \multirow{2}{*}{$\begin{array}{l}\text { Population Participants } \\
\text { (Mean Age, SD) }\end{array}$} & \multirow{2}{*}{ Patient Home } & \multicolumn{3}{|c|}{ Data } & \multirow{2}{*}{ Qualit } \\
\hline & & & As a Complement to the System & Collected through the Use of System & Transmission & \\
\hline Litt [44], 2009 & $\begin{array}{c}32 \text { IG } \\
22 \text { CG } \\
\text { Overall (41.0 } \pm 11.9)\end{array}$ & Yes & Pre and Post: MPI, CES-D & $\begin{array}{l}\text { Pan location, unpleasantness experienced, perceived control } \\
\text { over pain, catastrophization and coping, } 4 \text { times per day (from } \\
\text { 8 a.m. to } 10 \text { p.m.). Interactive voice recording was used } \\
\text { CBT: relaxation training, cognitive restructuring and } \\
\text { stress management }\end{array}$ & Instant & $\mathrm{H}$ \\
\hline Luckmann [76], 2010 & 4 & Yes & & $\begin{array}{l}\text { Pain intensity (NRS), location, activity and treatment } \\
\text { completed each 2-4 waking hours. Acute pain registered when } \\
\text { happens. Sleep report in the morning and end of day report } \\
\text { before sleep. Data integration with PHR }\end{array}$ & Instant & $\mathrm{L}$ \\
\hline Marceau [105], 2010 & $\begin{array}{l}\text { 67 IG (48.5 } \pm 11.6) \\
67 \text { CG }(50.5 \pm 11.0)\end{array}$ & No & & $\begin{array}{l}\text { BPI at each monthly clinic visit. Pre and post-treatment and } \\
\text { 5-month follow up: BPI, PCS, ODI, CES-D }\end{array}$ & Instant & $\mathrm{H}$ \\
\hline McClellan [29], 2009 & $\begin{array}{c}9 \text { IG } \\
10 \text { CG } \\
\text { Overall }(13.4 \pm 2.9)\end{array}$ & Yes & & $\begin{array}{l}\text { Pain intensity at morning and evening (10-point Likert scale), } \\
\text { pain location, sleep quality, and functional limitations once } \\
\text { a day } \\
\text { CBT: coping skills program, once a day. Parents presence } \\
\text { is allowed }\end{array}$ & Instant & $\mathrm{H}$ \\
\hline Oerlemans [38], 2011 & $\begin{array}{l}37 \text { IG }(35.9 \pm 11.7) \\
39 \text { CG }(40.6 \pm 15.5)\end{array}$ & Yes & $\begin{array}{l}\text { Pre and Post (upon treatment and 3-month follow } \\
\text { up): Pain intensity (5-point Likert scale), CFSBD, } \\
\text { IBS-QoL, PCS }\end{array}$ & $\begin{array}{l}\text { Pain intensity (5-point Likert scale) } 3 \text { times per day (morning, } \\
\text { afternoon and evening). Sleep quality and intended activities } \\
\text { for the day. (morning), accomplished activities, cognitions, and } \\
\text { feelings (afternoon), and satisfaction with activity level and } \\
\text { achievements of that day (evening) } \\
\text { CBT: situational feedback on their diaries from a psychologist }\end{array}$ & Instant & $\mathrm{H}$ \\
\hline Okifuji [106], 2011 & $81(28.8 \pm 6.2)$ & Yes & & $\begin{array}{l}\text { Overall pain (7-point Likert scale), fatigue, head pain, } \\
\text { emotional distress, abdominal pain, sense of relaxation, muscle } \\
\text { pain, and sense of swelling, } 3 \text { times per day (morning, early } \\
\text { afternoon, late afternoon) }\end{array}$ & Delayed & $\mathrm{L}$ \\
\hline Page [107], 2010 & $14(65.1)$ & No & Pre: PDQ-39, BDI-II, UPDRS & $\mathrm{MPQ}$, in the medical appointment & Delayed & $\mathrm{L}$ \\
\hline Palermo [33], 2004 & $\begin{array}{l}30 \text { IG }(12.3 \pm 2.4) \\
30 \text { CG }(12.3 \pm 3.0)\end{array}$ & Yes & Pre: CALI & $\begin{array}{l}\text { Pain intensity (Faces pain scale [108]), pain symptoms } \\
\text { (occurrence, location, duration, and emotional upset), CSI, and } \\
\text { CALI, once a day }\end{array}$ & Delayed & $\mathrm{H}$ \\
\hline Peters [109], 2000 & $80(40.6 \pm 6.7)$ & Yes & $\begin{array}{l}\text { Pre: MPI, SF-36, BSI } \\
\text { Post: CSQ ( } 6 \text { months follow up) }\end{array}$ & $\begin{array}{l}\text { Pain intensity (7-point scale) and signal controlled diary (items: } \\
\text { pain cognition, pain coping, sleep quality...), } 4 \text { times per day } \\
\text { between } 8 \text { a.m. and 9:30 p.m. }\end{array}$ & Delayed & $\mathrm{H}$ \\
\hline Roelofs [110], 2004 & $40(46.4 \pm 9.9)$ & Yes & Pre: TSK, QBPDS & $\begin{array}{l}\text { Pain intensity (PVAQ), TSK, } 8 \text { times per day between } 8 \text { a.m. } \\
\text { (weekend } 9 \text { a.m.) and } 10 \text { p.m. }\end{array}$ & Delayed & $\mathrm{L}$ \\
\hline Schurman [35], 2010 & $\begin{array}{c}10 \text { IG } \\
10 \text { CG } \\
\text { Overall }(12.2 \pm 2.8)\end{array}$ & Yes & $\begin{array}{l}\text { Pre and Post: BASC, PedsQL, completed by children } \\
\text { and parents }\end{array}$ & $\begin{array}{l}\text { Pain intensity (Faces pain scale Revised), once per day } \\
\text { (bedtime) } \\
\text { CBT: relaxation sessions, such as abdominal breathing, } \\
\text { progressive muscle relaxation, imagery, and autogenic } \\
\text { hand-warming. Multimedia content for home practice }\end{array}$ & Delayed & $\mathrm{H}$ \\
\hline Sorbi [111], 2007 & 5 & Yes & & $\begin{array}{l}\text { Pain intensity (VAS). 1st test run: } 4-5 \text { times per day. } 2 \text { nd test } \\
\text { run: } 2-3 \text { times per day } \\
\text { CBT: migraine headache, medication use, attack precursors, } \\
\text { self relaxation and other preventive behaviour }\end{array}$ & Instant & $\mathrm{L}$ \\
\hline
\end{tabular}


Table A1. Cont.

\begin{tabular}{|c|c|c|c|c|c|c|}
\hline \multirow{2}{*}{ Study/Year } & \multirow{2}{*}{$\begin{array}{l}\text { Population Participants } \\
\text { (Mean Age, SD) }\end{array}$} & \multirow{2}{*}{ Patient Home } & \multicolumn{3}{|c|}{ Data } & \multirow{2}{*}{ Quality } \\
\hline & & & As a Complement to the System & Collected through the Use of System & Transmission & \\
\hline Stinson [112], 2008 & $\begin{array}{l}\text { Study } 176(13.4 \pm 2.5) \\
\text { Study } 236(12.6 \pm 2.4)\end{array}$ & Yes & Post: PedsQL, PCQ & $\begin{array}{l}\text { Pain intensity, pain unpleasantness, pain's interference with } \\
\text { aspects of quality of life and other symptoms (e.g., stiffness } \\
\text { and fatigue) (VAS), } 3 \text { times per day (upon waking, after school, } \\
\text { and before bed) }\end{array}$ & Instant & $\mathrm{H}$ \\
\hline Stinson [113], 2012 & $\begin{array}{l}24 \text { children }(5.9 \pm 0.9) \\
77 \text { youth }(13.5 \pm 3.1)\end{array}$ & No & & $\begin{array}{l}\text { Pain intensity: faces pain scale (children), NRS (youth), in the } \\
\text { medical appointment }\end{array}$ & Instant & $\mathrm{H}$ \\
\hline Stone [31], 2003 & $\begin{array}{c}40 \text { IG }(43.0 \pm 9.0) \\
40 \text { CG }(48.0 \pm 10.8)\end{array}$ & Yes & Pre: MPQ-SF & BPI, PD-IIP, HAQ, 3 times per day (10 p.m., 4 a.m., 8 a.m.) & Delayed & $\mathrm{H}$ \\
\hline $\begin{array}{l}\text { Stone-Kelly [30,32], } \\
2003\end{array}$ & $\begin{array}{l}22 \text { IG } 3 \text { prompts/day } \\
(49.0 \pm 10.7) \\
22 \text { IG } 6 \text { prompts/day } \\
(53.5 \pm 10.4) \\
24 \text { IG } 12 \text { prompts/day } \\
(50.3 \pm 10.3) \\
23 \text { CG }(49.8 \pm 12.5)\end{array}$ & Yes & $\begin{array}{l}\text { Pre: Questionnaire to assess anxiety, stress, pain, health, } \\
\text { and quality of life } \\
\text { Pre/Treatment: Questionnaire, once a week, to assess } \\
\text { pain and mood, the momentary and the occurred over } \\
\text { the last } 7 \text { days } \\
\text { Treatment: Questionnaire once a week to assess } \\
\text { interference of ED with participants' daily routines }\end{array}$ & $\begin{array}{l}\text { Pain intensity (VAS), and other questions related to sensory, } \\
\text { affective and physical aspects, } 3,6 \text { or } 12 \text { times a day. Kelly's } \\
\text { study includes all the IGs }\end{array}$ & Delayed & $\mathrm{H}$ \\
\hline Turner [47], 2005 & $\begin{array}{r}61 \text { IG }(39.3 \pm 11.1) \\
65 \text { CG }(35.4 \pm 10.5)\end{array}$ & Yes & Pre: GCPS & $\begin{array}{l}\text { Pain intensity (NRS), pain-related activity interference, jaw use } \\
\text { limitations, and several questions adapted from CSQ, SOPA, } \\
\text { PCS, and DCI, } 3 \text { times per day (morning, afternoon, } \\
\text { and evening) } \\
\text { CBT: At each session activity goals were recommended } \\
\text { (correct jaw posture, progressive relaxation practice, breathing } \\
\text { exercises, physical exercise...) }\end{array}$ & Delayed & $\mathrm{H}$ \\
\hline Wallasch [114], 2012 & $545(43.1 \pm 12.9)$ & Yes & & MIDAS, GCPS, HADS, SF-12 & Delayed & $\mathrm{L}$ \\
\hline Weering [115], 2012 & $16(40.7 \pm 13.8)$ & Yes & Pre: $\mathrm{RMDQ}$, SoC & $\begin{array}{l}\text { Pain intensity (VAS), } 3 \text { times a day (noon, } 4 \text { p.m., } 8 \text { p.m.). } \\
\text { Integration with Body Area Network (BAN) }\end{array}$ & Instant & $\mathrm{L}$ \\
\hline Younger [116], 2009 & $10(46.5 \pm 10.3)$ & Yes & Treatment: FIQ every 2 weeks & $\begin{array}{l}\text { Fibromyalgia severity, average pain intensity, highest pain, } \\
\text { and other symptoms (fatigue, sadness, stress, sleep quality, } \\
\text { ability to think and remember ... ), once a day (night) }\end{array}$ & NR & $\mathrm{L}$ \\
\hline \multicolumn{7}{|c|}{ Web-based systems } \\
\hline Berman [41], 2009 & $\begin{array}{l}\text { 41 IG (64.3) } \\
37 \text { CG (67.5) }\end{array}$ & & Pre and Post: BPI, PSEQ, CED-S, STAI, PAQ, HDM & $\begin{array}{l}\text { Pain intensity (BPI), after logon and before logoff in the site } \\
\text { CBT: abdominal breathing, relaxation, writing about } \\
\text { experiences (positives or negatives), creative visual expression } \\
\text { and positive thinking. Audio, visual and textual content } \\
\text { related to pain }\end{array}$ & & $\mathrm{H}$ \\
\hline Buhrman [36], 2004 & $\begin{array}{l}22 \text { IG }(43.5 \pm 10.3) \\
29 \text { CG }(45.0 \pm 10.7)\end{array}$ & & Pre: HADS & $\begin{array}{l}\text { Pain intensity (VAS), } 3 \text { times per day (morning, noon and } \\
\text { evening). PAIRS, MPI, CSQ and HADS once a week } \\
\text { CBT: several modules (pain, stress, physical activities, problem } \\
\text { solving...) and slideshows and sound files for download }\end{array}$ & & $\mathrm{H}$ \\
\hline
\end{tabular}


Table A1. Cont.

\begin{tabular}{|c|c|c|c|c|c|c|}
\hline \multirow{2}{*}{ Study/Year } & \multirow{2}{*}{$\begin{array}{l}\text { Population Participants } \\
\text { (Mean Age, SD) }\end{array}$} & \multirow{2}{*}{ Patient Home } & \multicolumn{3}{|c|}{ Data } & \multirow{2}{*}{ Quality } \\
\hline & & & As a Complement to the System & Collected through the Use of System & Transmission & \\
\hline \multicolumn{7}{|c|}{ Web-based systems } \\
\hline Devineni [42], 2005 & $\begin{array}{l}39 \text { IG }(43.6 \pm 12.0) \\
47 \text { CG }(41.0 \pm 11.8)\end{array}$ & & & $\begin{array}{l}\text { Frequency, duration, and severity of pain, once a day } \\
\text { Pre/Post/Follow up: HSQ, CES-D, STAI, HDI } \\
\text { CBT: muscle relaxation program, and stress coping therapy }\end{array}$ & & $\mathrm{H}$ \\
\hline Hicks [43], 2006 & $\begin{array}{r}25 \text { IG }(12.1 \pm 2.0) \\
22 \text { CG }(11.3 \pm 2.2)\end{array}$ & & $\begin{array}{l}\text { Pre: PedsQL } \\
\text { Post: PedsQL (1-month and 3-month follow up) }\end{array}$ & $\begin{array}{l}\text { Pain intensity (NRS), } 4 \text { times per day } \\
\text { CBT: relaxation techniques, lifestyle (diet, exercise), } \\
\text { information related to pain }\end{array}$ & & $\mathrm{H}$ \\
\hline Hunt [51], 2009 & $\begin{array}{l}28 \text { IG }(39.0 \pm 10.0) \\
26 \text { CG }(38.0 \pm 12.0)\end{array}$ & & & $\begin{array}{l}\text { GSRS-IBS, IBS-QoL, ASI, GAD-Q and CPSQ, conducted at } \\
\text { pre-and post-treatment and 3-month follow-up } \\
\text { CBT: gastrointestinal symptoms and stress and on relaxation } \\
\text { training, stress management, catastrophic thinking, exposure } \\
\text { therapy and the social consequences of IBS }\end{array}$ & & $\mathrm{H}$ \\
\hline $\begin{array}{l}\text { Kristjansdottir [52], } \\
\quad 2011\end{array}$ & $6(36.3)$ & & Pre and Post: $C P A Q, P C S$ & $\begin{array}{l}\text { Pain intensity, interference of pain, planned and achieved } \\
\text { activities, feelings, pain-related fear, avoidance, } \\
\text { catastrophizing and acceptance, } \\
3 \text { times per day (morning, evening and a time randomly } \\
\text { chosen between } 11: 30 \text { a.m. and } 2 \text { p.m.) } \\
\text { CBT: feedback SMS with praise, encouragement messages, } \\
\text { and exercises }\end{array}$ & & $\mathrm{L}$ \\
\hline Ljótsson [45], 2010 & $\begin{array}{l}42 \text { IG }(36.4 \pm 10.1) \\
43 \mathrm{CG}(32.8 \pm 8.6)\end{array}$ & & Treatment: Gastrointestinal symptom diary & $\begin{array}{l}\text { GSRS-IBS, IBS-QoL, VSI, MADRS-S and SDS conducted at } \\
\text { pre-and post treatment. 3-month follow up: VSI, IBS-QoL and } \\
2 \text { weekly GSRS-IBS } \\
\text { CBT: mindfulness exercises program, and lifestyle strategies } \\
\text { (diet, exercise) }\end{array}$ & & $\mathrm{H}$ \\
\hline Lorig [39], 2008 & $\begin{array}{l}422 \text { IG }(52.2 \pm 10.9) \\
433 \text { CG }(52.5 \pm 12.2)\end{array}$ & & & $\begin{array}{l}\text { Pre and post treatment, and 6/12 months follow up: pain } \\
\text { intensity and fatigue (NRS), distress, activities limitations, } \\
\text { disabilities and HAQ } \\
\text { CBT: tailored exercises programmes and medication diaries }\end{array}$ & & $\mathrm{H}$ \\
\hline Palermo [37], 2009 & $\begin{array}{l}26 \text { IG }(14.3 \pm 2.1) \\
22 \text { CG }(15.3 \pm 1.8)\end{array}$ & & Pre and Post: RCADS, ARCS & $\begin{array}{l}\text { Pain intensity (NRS), CALI } \\
\text { CBT: two separate websites, one for child access and one for } \\
\text { parent access. The child access comprised eight treatment } \\
\text { modules (education about chronic pain, recognizing stress and } \\
\text { negative emotions, relaxation, distraction, cognitive skills, } \\
\text { sleep hygiene and lifestyle, staying active, relapse prevention). } \\
\text { Download of multimedia content. }\end{array}$ & & $\mathrm{H}$ \\
\hline Ruehlman [46], 2012 & $\begin{array}{c}162 \text { IG (19 78) } \\
143 \text { CG (19 78) }\end{array}$ & & & $\begin{array}{l}\text { CES-D, DASS, PCP-S and PCP-EA at pre-treatment, 7-weeks } \\
\text { and 14-weeks follow-up } \\
\text { CBT: several content such as interactive activity, } \\
\text { relaxation sessions }\end{array}$ & & $\mathrm{H}$ \\
\hline
\end{tabular}


Table A1. Cont.

\begin{tabular}{|c|c|c|c|c|c|c|}
\hline \multirow{2}{*}{ Study/Year } & \multirow{2}{*}{$\begin{array}{l}\text { Population Participants } \\
\text { (Mean Age, SD) }\end{array}$} & \multirow{2}{*}{ Patient Home } & \multicolumn{3}{|c|}{ Data } & \multirow{2}{*}{ Quality } \\
\hline & & & As a Complement to the System & Collected through the Use of System & Transmission & \\
\hline \multicolumn{7}{|c|}{ Web-based systems } \\
\hline Strom [40], 2000 & $\begin{array}{l}20 \text { IG (41.5) } \\
25 \text { CG (39.2) }\end{array}$ & & $\begin{array}{l}\text { Pre: Pain intensity (VAS), duration, BDI, HDI, MLPC. } \\
\text { Treatment: Number of times and the total time used } \\
\text { for training relaxation. } \\
\text { Post: Pain intensity (VAS) }\end{array}$ & CBT: several modules concerning relaxation & & $\mathrm{H}$ \\
\hline Williams [48], 2010 & $\begin{array}{l}59 \text { IG }(50.2 \pm 12.3) \\
59 \text { CG (50.8 } \pm 10.6)\end{array}$ & & Pre: MINI, PD-IIP & $\begin{array}{l}\text { SF-36, BPI, MFI, MOS-SS, CES-D, STPI and PGIC at pre and } \\
\text { post-treatment } \\
\text { CBT: multimedia content following topics: educational } \\
\text { lectures, symptom management and adaptive life style }\end{array}$ & & $\mathrm{H}$ \\
\hline
\end{tabular}
IG: Intervention Group; CG: Control Group; Q:Quality (H: Above average quality L: Below average quality); NR: Not Reported; ED: Electronic Diary; CBT: Cognitive-behavioural
Therapy. ABC: Addiction Behaviours Checklist [117]; AMS: Analysys of Musculoskeletal Symptoms [118]; ARCS: Adult Responses to Children's Symptoms Questionnaire [119]; ASEX: Arizona Sexual Experience [120]; ASI: Anxiety Sensitivity Index [121]; BASC: Behaviour Assessment System for Children [122]; BDI: Beck Depression Inventory [123]; BDI-II: BDI revised; BFI: Brief Fatigue Inventory [124]; BPI: Brief Pain Inventory [125]; BSI: Brief Symptom Inventory [126]; CALI: Child Activity Limitations Interview [127]; CALQ: Child Activity revised; BFI: Brief Fatigue Inventory [124]; BPI: Brief Pain Inventory [125]; BSI: Brief Symptom Inventory [128]; CES-D: Center for Epidemiological Studies Depression Scale [129]; CPAQ: Chronic Pain Acceptance Questionnaire [130]; CPEQ: Comprehensive Pain Evaluation Questionnaire [131]; CPSQ: Consequences of Physical Sensations Questionnaire [132]; COMM: Current Medication Misuse Measure [133]; CSI: Children's Somatisation Inventory [134]; CSQ: Coping Strategies Questionnaire [135]; CSFBD: Cognitive Scale for Functional Bowel Disorders [136]; DASS: Depression Anxiety Stress Scale [137]; DCI: Daily Coping Inventory [138]; EQ5D: Euro-QoL 5 [139]; FIQ: Fibromyalgia Impact Questionnaire [140]; GAD-Q: Generalized Anxiety Disorder Questionnaire [141]; GCPS: Graded Chronic Pain Scale [142]; GSRS-IBS: Gastrointestinal Symptom Rating Scale-Irritable Bowel Syndrome [143]; IBS-QoL: Irritable Bowel Syndrome Quality of Life [144]; IPAQ: International Physical Activity Questionnaire [145]; HADS: Hospital Anxiety and Depression Scale [146]; HAQ: Health Assessment Questionnaire [147]; HDI: Headache Disability Inventory [148]; HDM: Healthy Days Measures [149]; HSCL-25: Hopkins Symptom Check List [150]; HSQ: Headache Symptom Questionnaire [151]; MADRS-S: Montgomery Åsberg Depression Rating Scale-Self report [152]; MASQ: Multiple Ability Self-Report Questionnaire [153]; MDHAQ: Multidimensional Health Assessment Questionnaire [154]; MFI: Multidimensional Fatigue Inventory [155]; MHAQ: Modified Health Assessment Questionnaire [156]; MIDAS: MIgraine Disability Assessment Score [157]; MINI: Mini-International Neuropsychiatric Interview [158]; MLPC: Multidimensional Locus of Pain Control [159]; MOS-SS: Medical Outcomes Study Sleep Scale [160]; MPI: Multidimensional Pain Inventory [161]; MPQ: McGill Pain Questionnaire [162]; MPQ-SF: MPQ-Short Format; NRS: Numeric Rating Scale [163]; ODI: Oswestry Disability Index [164]; PAIRS: Pain Impairment Rating Scale [165]; PANAS: Positive and Negative Affect Schedule [166]; PANAS-C: PANAS for Children; PAQ: Pain Awareness Questionnaire [41]; PCP-EA: Profile of Chronic Pain Extended Assessment [167]; PCP-S: Profile of Chronic Pain: Screen [168]; PCQ: Pain Coping Questionnaire [169]; PCS: Pain Catastrophizing Scale [170]; PD-IIP: Personality Disorders Scale of the Inventory of Interpersonal Problems [171]; PD-Q: painDETECT questionnaire [172]; PDI: Pain Disability Index [173]; PDQ-39: Parkinson's Disease Questionnaire-39 [174]; PDUQ: Prescription Drug Use Questionnaire [175]; PedsQL: Pediatric Quality of Life Inventory [176]; PGIC: Patient Global Impression of Change [177]; PHQ: Patient Health Questionnaire [178]; PSEQ: Pain Self-efficacy Qute Activity Index [182]; RCADS: Revised Chis Anxiety and Sheehan Disability Scale [186], SF-36. MOS 36-ltem short-form [187] (SF-12 are a short version of SF-36); SOAPP-R. Screener and Opioid Assessment for Pain Patients-Revised [188] SoC: Stage of Change [189]; SOPA: Survey of Pain Attitudes [190] ; STAI: State-Trait Anxiety Inventory [191]; STPI: State-Trait Personality Inventory [192]; TSK: Tampa Scale for Kinesiophobia [193]; UPDRS: Unified Parkinson's Disease Rating Scale [194]; VAS: Visual Analogue Scale [195]; VSI: Visceral Sensitivity Index [196]. 


\section{Appendix A2}

The quality assessment tool which includes: (1) Formulation of the research question; (2) Specification of inclusion/exclusion criteria; (3) Sample description; (4) Design; (5) Technical description; (6) Description of study procedure; (7) Statistical analyses; (8) Conclusions supported by data; (9) Limitations of study analyzed explicitly; (10) Research questions are answered.

\section{Appendix A3}

Table A2. Risk of bias assessment.

\begin{tabular}{|c|c|c|c|c|c|c|}
\hline Study/Year & $\begin{array}{l}\text { Sequence } \\
\text { Generation }\end{array}$ & $\begin{array}{l}\text { Allocation } \\
\text { Concealment }\end{array}$ & $\begin{array}{c}\text { Blinding of } \\
\text { Participants, } \\
\text { Personnel and } \\
\text { Outcome Assessors }\end{array}$ & $\begin{array}{c}\text { Incomplete } \\
\text { Outcome } \\
\text { Data }\end{array}$ & $\begin{array}{l}\text { Free of } \\
\text { Selective } \\
\text { Outcome } \\
\text { Reporting }\end{array}$ & $\begin{array}{c}\text { Free of } \\
\text { Other } \\
\text { Sources of } \\
\text { Bias }\end{array}$ \\
\hline Berman [41], 2009 & Yes & No & No & Yes & Yes & No \\
\hline Buhrman [36], 2004 & Yes & Yes & No & Yes & Yes & Yes \\
\hline Devineni [42], 2005 & No & Yes & No & Yes & Yes & Yes \\
\hline Hicks [43], 2006 & Yes & Yes & No & No & Yes & Yes \\
\hline Hunt [51], 2009 & Yes & Yes & No & No & Yes & No \\
\hline Litt [44], 2009 & Yes & Yes & No & Unclear & Yes & Yes \\
\hline Ljótsson [45], 2010 & Yes & Yes & No & Unclear & Yes & Yes \\
\hline Lorig [39], 2008 & Yes & Yes & No & No & Yes & Yes \\
\hline Marceau [105], 2010 & Yes & Yes & No & No & Yes & Yes \\
\hline Oerlemans [38], 2011 & Yes & Yes & No & Unclear & Yes & No \\
\hline Palermo [37], 2009 & Yes & Yes & No & Yes & Yes & Yes \\
\hline Ruehlman [46], 2012 & Yes & Yes & No & Yes & Yes & No \\
\hline Schurman [35], 2010 & Yes & Yes & No & Yes & Yes & Yes \\
\hline Strom [40], 2000 & Yes & Yes & No & Yes & Yes & No \\
\hline Turner [47], 2005 & No & Yes & No & Yes & Yes & Yes \\
\hline Williams [48], 2010 & Yes & Yes & No & Unclear & Yes & Yes \\
\hline
\end{tabular}

\section{References}

1. Committee on Advancing Pain Research, Care, Institute of Medicine (U.S.). Relieving Pain in America: A Blueprint for Transforming Prevention, Care, Education, and Research; The National Academies Press: Washington, DC, USA, 2011.

2. Ashburn, M.A.; Staats, P.S. Management of chronic pain. Lancet 1999, 353, 1865-1869. [CrossRef]

3. Langley, P.; Muller-Schwefe, G.; Nicolaou, A.; Liedgens, H.; Pergolizzi, J.; Varrassi, G. The impact of pain on labor force participation, absenteeism and presenteeism in the European Union. J. Med. Econ. 2010, 13, 662-672. [CrossRef] [PubMed]

4. Stewart, W.F.; Ricci, J.A.; Chee, E.; Hahn, S.R.; Morganstein, D. Cost of lost productive work time among U.S. workers with depression. JAMA 2003, 289, 3135-3144. [CrossRef] [PubMed]

5. Apkarian, A.V.; Baliki, M.N.; Geha, P.Y. Towards a theory of chronic pain. Prog. Neurobiol. 2009, 87, 81-97. [CrossRef] [PubMed]

6. Mackintosh, C.; Elson, S. Chronic pain: Clinical features, assessment and treatment. Nurs. Stand. 2008, 23, 48-56. [CrossRef] [PubMed]

7. Thomas, T.; Robinson, C.; Champion, D.; McKell, M.; Pell, M. Prediction and assessment of the severity of post-operative pain and of satisfaction with management. Pain 1998, 75, 177-185. [CrossRef]

8. Hirsh, A.T.; George, S.Z.; Robinson, M.E. Pain assessment and treatment disparities: A virtual human technology investigation. Pain 2009, 143, 106-113. [CrossRef] [PubMed]

9. Giordano, J.; Abramson, K.; Boswell, M.V. Pain assessment: Subjectivity, objectivity, and the use of neurotechnology. Pain Phys. 2010, 13, 305-315.

10. Nekolaichuk, C.L.; Bruera, E.; Spachynski, K.; MacEachern, T.; Hanson, J.; Maguire, T.O. A comparison of patient and proxy symptom assessments in advanced cancer patients. Palliat. Med. 1999, 13, 311-323. [CrossRef] [PubMed] 
11. Pautex, S.; Berger, A.; Chatelain, C.; Herrmann, F.; Zulian, G.B. Symptom assessment in elderly cancer patients receiving palliative care. Crit. Rev. Oncol. Hematol. 2003, 47, 281-286. [CrossRef]

12. Weingarten, S.R.; Henning, J.M.; Badamgarav, E.; Knight, K.; Hasselblad, V.; Gano, A., Jr.; Ofman, J.J. Interventions used in disease management programmes for patients with chronic illnesswhich ones work? Meta-analysis of published reports. BMJ 2002, 325, 925. [CrossRef] [PubMed]

13. Escarrabill, J.; Marti, T.; Torrente, E. Good morning, doctor Google. Rev. Port. Pneumol. 2011, 17, $177-181$. [CrossRef] [PubMed]

14. Keogh, E.; Rosser, B.A.; Eccleston, C. e-Health and chronic pain management: Current status and developments. Pain 2010, 151, 18-21. [CrossRef] [PubMed]

15. Rosser, B.A.; Vowles, K.E.; Keogh, E.; Eccleston, C.; Mountain, G.A. Technologically-assisted behaviour change: A systematic review of studies of novel technologies for the management of chronic illness. J. Telemed. Telecare 2009, 15, 327-338. [CrossRef] [PubMed]

16. Ong, K.S.; Seymour, R.A. Pain measurement in humans. Surgeon 2004, 2, 15-27. [CrossRef]

17. Melzack, R.; Casey, K.L. Sensory, motivational, and central control determinants of pain: A new conceptual model. Skin Senses 1968, 423-443.

18. Fernandez, E.; Turk, D.C. Sensory and affective components of pain: Separation and synthesis. Psychol. Bull. 1992, 112, 205-217. [CrossRef] [PubMed]

19. Holroyd, K.A.; Talbot, F.; Holm, J.E.; Pingel, J.D.; Lake, A.E.; Saper, J.R. Assessing the dimensions of pain: A multitrait-multimethod evaluation of seven measures. Pain 1996, 67, 259-265. [CrossRef]

20. Kornbluth, I.D.; Freedman, M.K.; Holding, M.Y.; Overton, E.A.; Saulino, M.F. Interventions in chronic pain management. 4. Monitoring progress and compliance in chronic pain management. Arch. Phys. Med. Rehabil. 2008, 89, S51-S55. [CrossRef] [PubMed]

21. Higgins, J.P.T.; Green, S. Cochrane Handbook for Systematic Reviews of Interventions Version 5.1.0 (updated March 2011); Higgins, J.P.T., Green, S., Eds.; The Cochrane Collaboration: London, UK, 2011.

22. Higgins, J.P.T.; Altman, D.G.; Gøtzsche, P.C.; Jüni, P.; Moher, D.; Oxman, A.D.; Savović, J.; Schulz, K.F.; Weeks, L.; Sterne, J.A.C. The Cochrane Collaboration's tool for assessing risk of bias in randomised trials. BMJ 2011, 343. [CrossRef] [PubMed]

23. Bar-shalom, Y.; Li, X. Multitarget-Multisensor Tracking: Principles and Techniques; Yaakov Bar-Shalom: Storrs, CT, USA, 1995.

24. Bar-Shalom, Y.; Campo, L. The effect of the common process noise on the two-sensor fused-track covariance. IEEE Trans. Aerosp. Electron. Syst. 1986, AES-22, 803-805. [CrossRef]

25. Shin, V.; Shevlyakov, G.; Kim, K. A new fusion formula and its application to continuous-time linear systems with multisensor environment. Comput. Stat. Data Anal. 2007, 52, 840-854. [CrossRef]

26. Jamison, R.N.; Ross, E.L.; Michna, E.; Chen, L.Q.; Holcomb, C.; Wasan, A.D. Substance misuse treatment for high-risk chronic pain patients on opioid therapy: A randomized trial. Pain 2010, 150, 390-400. [CrossRef] [PubMed]

27. Wasan, A.D.; Ross, E.L.; Michna, E.; Chibnik, L.; Greenfield, S.F.; Weiss, R.D.; Jamison, R.N. Craving of prescription opioids in patients with chronic pain: A longitudinal outcomes trial. J. Pain 2012, 13, 146-154. [CrossRef] [PubMed]

28. Jamison, R.N.; Raymond, S.A.; Levine, J.G.; Slawsby, E.A.; Nedeljkovic, S.S.; Katz, N.P. Electronic diaries for monitoring chronic pain: 1-year validation study. Pain 2001, 91, 277-285. [CrossRef]

29. McClellan, C.B.; Schatz, J.C.; Puffer, E.; Sanchez, C.E.; Stancil, M.T.; Roberts, C.W. Use of handheld wireless technology for a home-based sickle cell pain management protocol. J. Pediatr. Psychol. 2009, 34, 564-573. [CrossRef] [PubMed]

30. Stone, A.A.; Broderick, J.E.; Schwartz, J.E.; Shiffman, S.; Litcher-Kelly, L.; Calvanese, P. Intensive momentary reporting of pain with an electronic diary: Reactivity, compliance, and patient satisfaction. Pain 2003, 104, 343-351. [CrossRef]

31. Stone, A.A.; Shiffman, S.; Schwartz, J.E.; Broderick, J.E.; Hufford, M.R. Patient compliance with paper and electronic diaries. Control. Clin. Trials 2003, 24, 182-199. [CrossRef]

32. Litcher-Kelly, L.; Stone, A.A.; Broderick, J.E.; Schwartz, J.E. Associations among pain intensity, sensory characteristics, affective qualities, and activity limitations in patients with chronic pain: A momentary, within-person perspective. J. Pain 2004, 5, 433-439. [CrossRef] [PubMed] 
33. Palermo, T.M.; Valenzuela, D.; Stork, P.P. A randomized trial of electronic versus paper pain diaries in children: Impact on compliance, accuracy, and acceptability. Pain 2004, 107, 213-219. [CrossRef] [PubMed]

34. Clauw, D.J.; Mease, P.; Palmer, R.H.; Gendreau, R.M.; Wang, Y. Milnacipran for the treatment of fibromyalgia in adults: A 15-week, multicenter, randomized, double-blind, placebo-controlled, multiple-dose clinical trial. Clin. Ther. 2008, 30, 1988-2004. [CrossRef] [PubMed]

35. Schurman, J.V.; Wu, Y.P.; Grayson, P.; Friesen, C.A. A pilot study to assess the efficacy of biofeedback-assisted relaxation training as an adjunct treatment for pediatric functional dyspepsia associated with duodenal eosinophilia. J. Pediatr. Psychol. 2010, 35, 837-847. [CrossRef] [PubMed]

36. Buhrman, M.; Fältenhag, S.; Ström, L.; Andersson, G. Controlled trial of Internet-based treatment with telephone support for chronic back pain. Pain 2004, 111, 368-377. [CrossRef] [PubMed]

37. Palermo, T.M.; Wilson, A.C.; Peters, M.; Lewandowski, A.; Somhegyi, H. Randomized controlled trial of an internet-delivered family cognitive-behavioral therapy intervention for children and adolescents with chronic pain. Pain 2009, 146, 205-213. [CrossRef] [PubMed]

38. Oerlemans, S.; van Cranenburgh, O.; Herremans, P.-J.; Spreeuwenberg, P.; van Dulmen, S. Intervening on cognitions and behavior in irritable bowel syndrome: A feasibility trial using PDAs. J. Psychosom. Res. 2011, 70, 267-277. [CrossRef] [PubMed]

39. Lorig, K.R.; Ritter, P.L.; Laurent, D.D.; Plant, K. The internet-based arthritis self-management program: A one-year randomized trial for patients with arthritis or fibromyalgia. Arthritis Care Res. 2008, 59, 1009-1017. [CrossRef] [PubMed]

40. Strom, L.; Pettersson, R.; Andersson, G. A controlled trial of self-help treatment of recurrent headache conducted via the Internet. J. Consult. Clin. Psychol. 2000, 68, 722-727. [CrossRef] [PubMed]

41. Berman, R.L.H.; Iris, M.A.; Bode, R.; Drengenberg, C. The Effectiveness of an online mind-body intervention for older adults with chronic pain. J. Pain 2009, 10, 68-79. [CrossRef] [PubMed]

42. Devineni, T.; Blanchard, E.B. A randomized controlled trial of an internet-based treatment for chronic headache. Behav. Res. Ther. 2005, 43, 277-292. [CrossRef] [PubMed]

43. Hicks, C.L.; von Baeyer, C.L.; McGrath, P.J. Online Psychological treatment for pediatric recurrent pain: A randomized evaluation. J. Pediatr. Psychol. 2006, 31, 724-736. [CrossRef] [PubMed]

44. Litt, M.D.; Shafer, D.M.; Ibanez, C.R.; Kreutzer, D.L.; Tawfik-Yonkers, Z. Momentary pain and coping in temporomandibular disorder pain: Exploring mechanisms of cognitive behavioral treatment for chronic pain. Pain 2009, 145, 160-168. [CrossRef] [PubMed]

45. Ljótsson, B.; Falk, L.; Vesterlund, A.W.; Hedman, E.; Lindfors, P.; Rück, C.; Hursti, T.; Andréewitch, S.; Jansson, L.; Lindefors, N.; Andersson, G. Internet-delivered exposure and mindfulness based therapy for irritable bowel syndrome-A randomized controlled trial. Behav. Res. Ther. 2010, 48, 531-539. [CrossRef] [PubMed]

46. Ruehlman, L.S.; Karoly, P.; Enders, C. A randomized controlled evaluation of an online chronic pain self management program. Pain 2012, 153, 319-330. [CrossRef] [PubMed]

47. Turner, J.A.; Mancl, L.; Aaron, L.A. Brief cognitive-behavioral therapy for temporomandibular disorder pain: Effects on daily electronic outcome and process measures. Pain 2005, 117, 377-387. [CrossRef] [PubMed]

48. Williams, D.A.; Kuper, D.; Segar, M.; Mohan, N.; Sheth, M.; Clauw, D.J. Internet-enhanced management of fibromyalgia: A randomized controlled trial. Pain 2010, 151, 694-702. [CrossRef] [PubMed]

49. Macea, D.D.; Gajos, K.; Calil, Y.A.D.; Fregni, F. The efficacy of web-based cognitive behavioral interventions for chronic pain: A systematic review and meta-analysis. J. Pain 2010, 11, 917-929. [CrossRef] [PubMed]

50. Broderick, J.E.; Schwartz, J.E.; Vikingstad, G.; Pribbernow, M.; Grossman, S.; Stone, A.A. The accuracy of pain and fatigue items across different reporting periods. Pain 2008, 139, 146-157. [CrossRef] [PubMed]

51. Hunt, M.G.; Moshier, S.; Milonova, M. Brief cognitive-behavioral internet therapy for irritable bowel syndrome. Behav. Res. Ther. 2009, 47, 797-802. [CrossRef] [PubMed]

52. Kristjansdottir, O.; Fors, E.; Eide, E.; Finset, A.; van Dulmen, S.; Wigers, S.; Eide, H. Written online situational feedback via mobile phone to support self-management of chronic widespread pain: A usability study of a web-based intervention. BMC Musculoskelet. Disord. 2011, 12, 51. [CrossRef] [PubMed]

53. Dearnley, C.; Haigh, J.; Fairhall, J. Using mobile technologies for assessment and learning in practice settings: A case study. Nurse Educ. Pract. 2008, 8, 197-204. [CrossRef] [PubMed] 
54. Dworkin, R.H.; Turk, D.C.; Peirce-Sandner, S.; Burke, L.B.; Farrar, J.T.; Gilron, I.; Jensen, M.P.; Katz, N.P.; Raja, S.N.; Rappaport, B.A.; et al. Considerations for improving assay sensitivity in chronic pain clinical trials: IMMPACT recommendations. Pain 2012, 153, 1148-1158. [CrossRef] [PubMed]

55. Burton, C.; Weller, D.; Sharpe, M. Are electronic diaries useful for symptoms research? A systematic review. J. Psychosom. Res. 2007, 62, 553-561. [CrossRef] [PubMed]

56. Palermo, T.M.; Eccleston, C.; Lewandowski, A.S.; Williams, A.C.; Morley, S. Randomized controlled trials of psychological therapies for management of chronic pain in children and adolescents: An updated meta-analytic review. Pain 2010, 148, 387-397. [CrossRef] [PubMed]

57. Kar, N. Cognitive behavioral therapy for the treatment of post-traumatic stress disorder: A review. Neuropsychiatr. Dis. Treat. 2011, 7, 167-181. [CrossRef] [PubMed]

58. Hay, E.M.; Mullis, R.; Lewis, M.; Vohora, K.; Main, C.J.; Watson, P.; Dziedzic, K.S.; Sim, J.; Lowe, C.M.; Croft, P.R. Comparison of physical treatments versus a brief pain-management programme for back pain in primary care: A randomised clinical trial in physiotherapy practice. Lancet 2005, 365, 2024-2030. [CrossRef]

59. Morley, S.; Eccleston, C.; Williams, A. Systematic review and meta-analysis of randomized controlled trials of cognitive behaviour therapy and behaviour therapy for chronic pain in adults, excluding headache. Pain 1999, 80, 1-13. [CrossRef]

60. Marhold, C.; Linton, S.J.; Melin, L. A cognitive-behavioral return-to-work program: Effects on pain patients with a history of long-term versus short-term sick leave. Pain 2001, 91, 155-163. [CrossRef]

61. Ektor-Andersen, J.; Ingvarsson, E.; Kullendorff, M.; Orbaek, P. High cost-benefit of early team-based biomedical and cognitive-behaviour intervention for long-term pain-related sickness absence. J. Rehabil. Med. 2008, 40, 1-8. [CrossRef] [PubMed]

62. Schonauer, C.; Pintaric, T.; Kaufmann, H.; Jansen-Kosterink, S.; Vollenbroek-Hutten, M. Chronic pain rehabilitation with a serious game using multimodal input. In Proceedings of the International Conference on Virtual Rehabilitation (ICVR), Zurich, Switzerland, 27-29 June 2011; pp. 1-8.

63. Fuchslocher, A.; Niesenhaus, J.; Krämer, N. Serious games for health: An empirical study of the game "Balance" for teenagers with diabetes mellitus. Entertain. Comput. 2011, 2, 97-101. [CrossRef]

64. Georgoulis, S.; Eleftheriadis, S.; Tzionas, D.; Vrenas, K.; Petrantonakis, P.; Hadjileontiadis, L.J. Epione: An innovative pain management system using facial expression analysis, biofeedback and augmented reality-based distraction. In Proceedings of the 2010 2nd International Conference on Intelligent Networking and Collaborative Systems (INCOS), Thessaloniki, Greece, 24-26 November 2010; pp. 259-266.

65. Hoffman, H.G.; Patterson, D.R.; Carrougher, G.J. Use of virtual reality for adjunctive treatment of adult burn pain during physical therapy: A controlled study. Clin. J. Pain 2000, 16, 244-250. [CrossRef] [PubMed]

66. Lewis, M. Analysis of the roles of "serious games" in helping teach health-related knowledge and skills and in changing behavior. J. Diabetes Sci. Technol. 2007, 1, 918-920. [CrossRef] [PubMed]

67. Howell, J.; Conatser, R.; Williams, R.; Burns, J.; Eland, D. The virtual haptic back: A simulation for training in palpatory diagnosis. BMC Med. Educ. 2008, 8, 14. [CrossRef] [PubMed]

68. Kew, S. Text messaging: An innovative method of data collection in medical research. BMC Res. Notes 2010, 3, 342. [CrossRef] [PubMed]

69. Axén, I.; Bodin, L.; Bergström, G.; Halasz, L.; Lange, F.; Lövgren, P.; Rosenbaum, A.; Leboeuf-Yde, C.; Jensen, I. Clustering patients on the basis of their individual course of low back pain over a six month period. BMC Musculoskelet. Disord. 2011, 12, 99. [CrossRef] [PubMed]

70. Axén, I.; Bodin, L.; Bergström, G.; Halasz, L.; Lange, F.; Lövgren, P.W.; Rosenbaum, A.; Leboeuf-Yde, C.; Jensen, I. The use of weekly text messaging over 6 months was a feasible method for monitoring the clinical course of low back pain in patients seeking chiropractic care. J. Clin. Epidemiol. 2012, 65, 454-461. [CrossRef] [PubMed]

71. Jespersen, T.; Jorgensen, M.; Hansen, J.; Holtermann, A.; Sogaard, K. The relationship between low back pain and leisure time physical activity in a working population of cleaners-A study with weekly follow-ups for 1 year. BMC Musculoskelet. Disord. 2012, 13, 28. [CrossRef] [PubMed]

72. Giske, L.; Sandvik, L.; Røe, C. Comparison of daily and weekly retrospectively reported pain intensity in patients with localized and generalized musculoskeletal pain. Eur. J. Pain 2010, 14, 959-965. [CrossRef] [PubMed]

73. Dijkstra, A.; de Vries, H. The development of computer-generated tailored interventions. Patient Educ. Counsel. 1999, 36, 193-203. [CrossRef] 
74. Suggs, L.S. A 10-year retrospective of research in new technologies for health communication. J. Health Commun. 2006, 11, 61-74. [CrossRef] [PubMed]

75. Trevena, L.J.; Barratt, A.; Butow, P.; Caldwell, P. A systematic review on communicating with patients about evidence. J. Eval. Clin. Pract. 2006, 12, 13-23. [CrossRef] [PubMed]

76. Luckmann, R.; Vidal, A. Design of a handheld electronic pain, treatment and activity diary. J. Biomed. Inform. 2010, 43, S32-S36. [CrossRef] [PubMed]

77. Handel, M.J. mHealth (Mobile Health)—Using Apps for health and wellness. Explore 2011, 7, $256-261$. [CrossRef] [PubMed]

78. Rosser, B.A.; Eccleston, C. Smartphone applications for pain management. J. Telemed. Telecare 2011, 17, 308-312. [CrossRef] [PubMed]

79. Ozdalga, E.; Ozdalga, A.; Ahuja, N. The smartphone in medicine: A review of current and potential use among physicians and students. J. Med. Internet Res. 2012, 14, e128. [CrossRef] [PubMed]

80. Greysen, S.R.; Kind, T.; Chretien, K. Online professionalism and the mirror of social media. J. Gen. Internal Med. 2010, 25, 1227-1229. [CrossRef] [PubMed]

81. Ahmed, S.; Abdullah, A. Telemedicine in a cloud-A review. In Proceedings of the 2011 IEEE Symposium on Computers Informatics (ISCI), Kuala Lumpur, Malaysia, 20-23 March 2011; pp. 776-781.

82. Pombo, N.; Araújo, P.; Viana, J.; Junior, B.; Serrano, R. Contribution of web services to improve pain diaries experience. In Proceedings of The International MultiConference of Engineers and Computer Scientists, Hong Kong, China, 14-16 March 2012; Volume 1, pp. 589-592.

83. Leow, J.J.; Pozo, M.E.; Groen, R.S.; Kushner, A.L. Social media in low-resource settings: A role for Twitter and Facebook in global surgery? Surgery 2012, 151, 767-769. [CrossRef] [PubMed]

84. Allen, K.D.; Coffman, C.J.; Golightly, Y.M.; Stechuchak, K.M.; Keefe, F.J. Daily pain variations among patients with hand, hip, and knee osteoarthritis. Osteoarthr. Cartil. 2009, 17, 1275-1282. [CrossRef] [PubMed]

85. Allen, K.D.; Coffman, C.J.; Golightly, Y.M.; Stechuchak, K.M.; Voils, C.I.; Keefe, F.J. Comparison of pain measures among patients with osteoarthritis. J. Pain 2010, 11, 522-527. [CrossRef] [PubMed]

86. Anatchkova, M.D.; Saris-Baglama, R.N.; Kosinski, M.; Bjorner, J.B. Development and preliminary testing of a computerized adaptive assessment of chronic pain. J. Pain 2009, 10, 932-943. [CrossRef] [PubMed]

87. Hahn, E.A.; Cella, D.; Bode, R.K.; Gershon, R.; Lai, J.S. Item banks and their potential applications to health status assessment in diverse populations. Med. Care 2006, 44, S189-S197. [CrossRef] [PubMed]

88. Badr, H.; Laurenceau, J.-P.; Schart, L.; Basen-Engquist, K.; Turk, D. The daily impact of pain from metastatic breast cancer on spousal relationships: A dyadic electronic diary study. Pain 2010, 151, 644-654. [CrossRef] [PubMed]

89. Mahn, F.; Hullemann, P.; Gockel, U.; Brosz, M.; Freynhagen, R.; Tölle, T.R.; Baron, R. Sensory symptom profiles and co-morbidities in painful radiculopathy. PLoS ONE 2011, 6, e18018. [CrossRef] [PubMed]

90. Baron, R.; Tölle, T.R.; Gockel, U.; Brosz, M.; Freynhagen, R. A cross-sectional cohort survey in 2100 patients with painful diabetic neuropathy and postherpetic neuralgia: Differences in demographic data and sensory symptoms. Pain 2009, 146, 34-40. [CrossRef] [PubMed]

91. Broderick, J.E.; Schwartz, J.E.; Schneider, S.; Stone, A.A. Can end-of-day reports replace momentary assessment of pain and fatigue? J. Pain 2009, 10, 274-281. [CrossRef] [PubMed]

92. Schneider, S.; Stone, A.A.; Schwartz, J.E.; Broderick, J.E. Peak and end effects in patients' daily recall of pain and fatigue: A within-subjects analysis. J. Pain 2011, 12, 228-235. [CrossRef] [PubMed]

93. Connelly, M.; Anthony, K.K.; Sarniak, R.; Bromberg, M.H.; Gil, K.M.; Schanberg, L.E. Parent pain responses as predictors of daily activities and mood in children with juvenile idiopathic arthritis: The utility of electronic diaries. J. Pain Symptom Manag. 2010, 39, 579-590. [CrossRef] [PubMed]

94. Gaertner, J.; Elsner, F.; Pollmann-Dahmen, K.; Radbruch, L.; Sabatowski, R. Electronic pain diary: A randomized crossover study. J. Pain Symptom Manag. 2004, 28, 259-267. [CrossRef] [PubMed]

95. Ghinea, G.; Spyridonis, F.; Serif, T.; Frank, A.O. 3-D pain drawings-mobile data collection using a PDA. IEEE Trans. Inf. Technol. Biomed. 2008, 12, 27-33. [CrossRef] [PubMed]

96. Heiberg, T.; Kvien, T.K.; Dale, Ø.; Mowinckel, P.; Aanerud, G.J.; Songe-Møller, A.B.; Uhlig, T.; Hagen, K.B. Daily health status registration (patient diary) in patients with rheumatoid arthritis: A comparison between personal digital assistant and paper-pencil format. Arthritis Care Res. 2007, 57, 454-460. [CrossRef] [PubMed] 
97. Jamison, R.N.; Gracely, R.H.; Raymond, S.A.; Levine, J.G.; Marino, B.; Herrmann, T.J.; Daly, M.; Fram, D.; Katz, N.P. Comparative study of electronic vs. paper VAS ratings: A randomized, crossover trial using healthy volunteers. Pain 2002, 99, 341-347. [CrossRef]

98. Jamison, R.N.; Raymond, S.A.; Slawsby, E.A.; McHugo, G.J.; Baird, J.C. Pain assessment in patients with low back pain: Comparison of weekly recall and momentary electronic data. J. Pain 2006, 7, 192-199. [CrossRef] [PubMed]

99. Koroschetz, J.; Rehm, S.; Gockel, U.; Brosz, M.; Freynhagen, R.; Tölle, T.; Baron, R. Fibromyalgia and neuropathic pain-Differences and similarities. A comparison of 3057 patients with diabetic painful neuropathy and fibromyalgia. BMC Neurol. 2011, 11, 55. [CrossRef] [PubMed]

100. Kvien, T.K.; Mowinckel, P.; Heiberg, T.; Dammann, K.L.; Dale, Ø.; Aanerud, G.J.; Alme, T.N.; Uhlig, T. Performance of health status measures with a pen based personal digital assistant. Ann. Rheum. Dis. 2005, 64, 1480-1484. [CrossRef] [PubMed]

101. Lewandowski, A.S.; Palermo, T.M.; De la Motte, S.; Fu, R. Temporal daily associations between pain and sleep in adolescents with chronic pain versus healthy adolescents. Pain 2010, 151, 220-225. [CrossRef] [PubMed]

102. Levin, E.; Levin, A. Evaluation of spoken dialogue technology for real-time health data collection. J. Med. Internet Res. 2006, 8, e30. [CrossRef] [PubMed]

103. $\mathrm{Li}, \mathrm{L}$. The effect of neuragen $\mathrm{PN}(\mathrm{R})$ on neuropathic pain: A randomized, double blind, placebo controlled clinical trial. BMC Complement. Altern. Med. 2010, 10, 22. [CrossRef] [PubMed]

104. Lind, L.; Karlsson, D.; Fridlund, B. Patients' use of digital pens for pain assessment in advanced palliative home healthcare. Int. J. Med. Informa. 2008, 77, 129-136. [CrossRef] [PubMed]

105. Marceau, L.D.; Link, C.L.; Smith, L.D.; Carolan, S.J.; Jamison, R.N. In-clinic use of electronic pain diaries: Barriers of implementation among pain physicians. J. Pain Symptom Manag. 2010, 40, 391-404. [CrossRef] [PubMed]

106. Okifuji, A.; Bradshaw, D.H.; Donaldson, G.W.; Turk, D.C. Sequential analyses of daily symptoms in women with fibromyalgia syndrome. J. Pain 2011, 12, 84-93. [CrossRef] [PubMed]

107. Page, D.B.; Weaver, F.; Wilkie, D.J.; Simuni, T. A computerized survey of pain in Parkinson's disease patients: A pilot feasibility study. Parkinsonism Relat. Disord. 2010, 16, 139-141. [CrossRef] [PubMed]

108. Bieri, D.; Reeve, R.A.; Champion, G.D.; Addicoat, L.; Ziegler, J.B. The faces pain scale for the self-assessment of the severity of pain experienced by children: Development, initial validation, and preliminary investigation for ratio scale properties. Pain 1990, 41, 139-150. [CrossRef]

109. Peters, M.L.; Sorbi, M.J.; Kruise, D.A.; Kerssens, J.J.; Verhaak, P.F.M.; Bensing, J.M. Electronic diary assessment of pain, disability and psychological adaptation in patients differing in duration of pain. Pain 2000, 84, 181-192. [CrossRef]

110. Roelofs, J.; Peters, M.L.; Patijn, J.; Schouten, E.G.W.; Vlaeyen, J.W.S. Electronic diary assessment of pain-related fear, attention to pain, and pain intensity in chronic low back pain patients. Pain 2004, 112, 335-342. [CrossRef] [PubMed]

111. Sorbi, J.M.; Mak, B.S.; Houtveen, H.J.; Kleiboer, M.A.; van Doornen, J.L. Mobile web-based monitoring and coaching: Feasibility in chronic migraine. J. Med. Internet Res. 2007, 9, e38. [CrossRef] [PubMed]

112. Stinson, J.N.; Stevens, B.J.; Feldman, B.M.; Streiner, D.; McGrath, P.J.; Dupuis, A.; Gill, N.; Petroz, G.C. Construct validity of a multidimensional electronic pain diary for adolescents with arthritis. Pain 2008, 136, 281-292. [CrossRef] [PubMed]

113. Stinson, J.; Connelly, M.; Jibb, L.; Schanberg, L.; Walco, G.; Spiegel, L.; Tse, S.; Chalom, E.; Chira, P.; Rapoff, M. Developing a standardized approach to the assessment of pain in children and youth presenting to pediatric rheumatology providers: A Delphi survey and consensus conference process followed by feasibility testing. Pediatr. Rheumatol. 2012, 10, 7. [CrossRef] [PubMed]

114. Wallasch, T.-M.; Hermann, C. Validation of criterion-based patient assignment and treatment effectiveness of a multidisciplinary modularized managed care program for headache. J. Headache Pain 2012, 13, 379-387. [CrossRef] [PubMed]

115. Van Weering, M.; Vollenbroek-Hutten, M.; Hermens, H. Do personalized feedback messages about activity patterns stimulate patients with chronic low back pain to change their activity behavior on a short term notice? Appl. Psychophysiol. Biofeedback 2012, 37, 81-89. [CrossRef] [PubMed] 
116. Younger, J.; Mackey, S. Fibromyalgia symptoms are reduced by low-dose naltrexone: A pilot study. Pain Med. 2009, 10, 663-672. [CrossRef] [PubMed]

117. Wu, S.M.; Compton, P.; Bolus, R.; Schieffer, B.; Pham, Q.; Baria, A.; van Vort, W.; Davis, F.; Shekelle, P.; Naliboff, B.D. The addiction behaviors checklist: Validation of a new clinician-based measure of inappropriate opioid use in chronic pain. J. Pain Symptom Manag. 2006, 32, 342-351. [CrossRef] [PubMed]

118. Kuorinka, I.; Jonsson, B.; Kilbom, A.; Vinterberg, H.; Biering-Sørensen, F.; Andersson, G.; Jørgensen, K. Standardised nordic questionnaires for the analysis of musculoskeletal symptoms. Appl. Ergon. 1987, 18, 233-237. [CrossRef]

119. Walker, L.S.; Levy, R.L.; Whitehead, W.E. Validation of a measure of protective parent responses to children's pain. Clin. J. Pain 2006, 22, 712-716. [CrossRef] [PubMed]

120. McGahuey, C.A.; Gelenberg, A.J.; Laukes, C.A.; Moreno, F.A.; Delgado, P.L.; McKnight, K.M.; Manber, R. The arizona sexual experience scale (ASEX): Reliability and validity. J. Sex Marital. Ther. 2000, 26, 25-40. [PubMed]

121. Peterson, R.A.; Heilbronner, R.L. The anxiety sensitivity index: Construct validity and factor analytic structure. J. Anxiety Disord. 1987, 1, 117-121. [CrossRef]

122. Reynolds, C.R. Behavior assessment system for children. In The Corsini Encyclopedia of Psychology; John Wiley \& Sons, Inc.: Hoboken, NJ, USA, 2010.

123. Beck, A.T.; Ward, C.H.; Mendelson, M.; Mock, J.; Erbaugh, J. An inventory for measuring depression. Arch. Gen. Psychiatry 1961, 4, 561-571. [CrossRef] [PubMed]

124. Mendoza, T.R.; Wang, X.S.; Cleeland, C.S.; Morrissey, M.; Johnson, B.A.; Wendt, J.K.; Huber, S.L. The rapid assessment of fatigue severity in cancer patients: Use of the brief fatigue inventory. Cancer 1999, 85, 1186-1196. [CrossRef]

125. Cleeland, C.S.; Ryan, K.M. Pain assessment: Global use of the brief pain inventory. Ann. Acad. Med. Singap. 1994, 23, 129-138. [PubMed]

126. Derogatis, L.R.; Melisaratos, N. The brief symptom inventory: An introductory report. Psychol. Med. 1983, 13, 595-605. [CrossRef] [PubMed]

127. Palermo, T.M.; Witherspoon, D.; Valenzuela, D.; Drotar, D.D. Development and validation of the Child activity limitations interview: A measure of pain-related functional impairment in school-age children and adolescents. Pain 2004, 109, 461-470. [CrossRef] [PubMed]

128. Hainsworth, K.R.; Davies, W.H.; Khan, K.A.; Weisman, S.J. Development and preliminary validation of the child activity limitations questionnaire: Flexible and efficient assessment of pain-related functional disability. J. Pain 2007, 8, 746-752. [CrossRef] [PubMed]

129. Radloff, L.S. The CES-D scale. Appl. Psychol. Meas. 1977, 1, 385-401. [CrossRef]

130. McCracken, L.M.; Vowles, K.E.; Eccleston, C. Acceptance of chronic pain: Component analysis and a revised assessment method. Pain 2004, 107, 159-166. [CrossRef] [PubMed]

131. Jamison, R.N. Mastering Chronic Pain: A Professional's Guide to Behavioral Treatment; Professional Resource Exchange Inc.: Sarasota, FL, USA, 1996.

132. Hunt, M.G.; Milonova, M.; Moshier, S. Catastrophizing the consequences of gastrointestinal symptoms in irritable bowel syndrome. J. Cogn. Psychother. 2009, 23, 160-173. [CrossRef]

133. Butler, S.F.; Budman, S.H.; Fernandez, K.C.; Houle, B.; Benoit, C.; Katz, N.; Jamison, R.N. Development and validation of the current opioid misuse measure. Pain 2007, 130, 144-156. [CrossRef] [PubMed]

134. Garber, J.; Walker, L.S.; Zeman, J. Somatization symptoms in a community sample of children and adolescents: Further validation of the children's somatization inventory. Psychol. Assess. 1991, 3, 588-595. [CrossRef]

135. Rosenstiel, A.K.; Keefe, F.J. The use of coping strategies in chronic low back pain patients: Relationship to patient characteristics and current adjustment. Pain 1983, 17, 33-44. [CrossRef]

136. Toner, B.B.; Stuckless, N.; Ali, A.; Downie, F.; Emmott, S.; Akman, D. The development of a cognitive scale for functional bowel disorders. Psychosom. Med. 1998, 60, 492-497. [CrossRef] [PubMed]

137. Crawford, J.R.; Henry, J.D. The depression anxiety stress scales (DASS): Normative data and latent structure in a large non-clinical sample. Br. J. Clin. Psychol. 2003, 42, 111-131. [CrossRef] [PubMed]

138. Stone, A.A.; Neale, J.M. New measure of daily coping: Development and preliminary results. J. Pers. Soc. Psychol. 1984, 46, 892-906. [CrossRef]

139. EuroQol Group. EuroQol-A new facility for the measurement of health-related quality of life. Health Policy 1990, 16, 199-208. 
140. Burckhardt, C.S.; Clark, S.R.; Bennett, R.M. The fibromyalgia impact questionnaire: Development and validation. J. Rheumatol. 1991, 18, 728-733. [PubMed]

141. Newman, M.G.; Zuellig, A.R.; Kachin, K.E.; Constantino, M.J.; Przeworski, A.; Erickson, T.; Cashman-McGrath, L. Preliminary reliability and validity of the generalized anxiety disorder questionnaire-IV: A revised self-report diagnostic measure of generalized anxiety disorder. Behav. Ther. 2002, 33, 215-233. [CrossRef]

142. Korff, M.V.; Ormel, J.; Keefe, F.J.; Dworkin, S.F. Grading the severity of chronic pain. Pain 1992, 50, $133-149$. [CrossRef]

143. Svedlund, J.; Sjodin, I.; Dotevall, G. GSRS-A clinical rating scale for gastrointestinal symptoms in patients with irritable bowel syndrome and peptic ulcer disease. Dig. Dis. Sci. 1988, 33, 129-134. [CrossRef] [PubMed]

144. Patrick, D.; Drossman, D.; Frederick, I.; Dicesare, J.; Puder, K. Quality of life in persons with irritable bowel syndrome (development and validation of a new measure). Dig. Dis. Sci. 1998, 43, 400-411. [CrossRef] [PubMed]

145. Craig, C.L.; Marshall, A.L.; Sjostrom, M.; Bauman, A.E.; Booth, M.L.; Ainsworth, B.E.; Pratt, M.; Ekelund, U.; Yngve, A.; Sallis, J.F.; Oja, P. International physical activity questionnaire: 12-country reliability and validity. Med. Sci. Sports Exerc. 2003, 35, 1381-1395. [CrossRef] [PubMed]

146. Zigmond, A.S.; Snaith, R.P. The hospital anxiety and depression scale. Acta Psychiatr. Scand. 1983, 67, 361-370. [CrossRef] [PubMed]

147. Ramey, D.R.; Raynauld, J.-P.; Fries, J.F. The health assessment questionnaire 1992. Status and review. Arthritis Rheum. 1992, 5, 119-129. [CrossRef]

148. Jacobson, G.P.; Ramadan, N.M.; Aggarwal, S.K.; Newman, C.W. The henry ford hospital headache disability inventory (HDI). Neurology 1994, 44, 837-842. [CrossRef] [PubMed]

149. Moriarty, D.; Zack, M.; Kobau, R. The centers for disease control and prevention's healthy days measures-Population tracking of perceived physical and mental health over time. Health Qual. Life Outcomes 2003, 1, 37. [CrossRef] [PubMed]

150. Derogatis, L.R.; Lipman, R.S.; Rickels, K.; Uhlenhuth, E.H.; Covi, L. The hopkins symptom checklist (HSCL). A measure of primary symptom dimensions. Mod. Probl. Pharmacopsychiat. 1974, 7, 79-110.

151. Arena, J.; Blanchard, E.; Andrasik, F.; Dudek, B. The headache symptom questionnaire: Discriminant classificatory ability and headache syndromes suggested by a factor analysis. J. Behav. Assess. 1982, 4, 55-69. [CrossRef]

152. Svanborg, P.; Asberg, M. A new self-rating scale for depression and anxiety states based on the comprehensive psychopathological rating scale. Acta Psychiatr. Scand. 1994, 89, 21-28. [CrossRef] [PubMed]

153. Seidenberg, M.; Haltiner, A.; Taylor, M.A.; Hermann, B.B.; Wyler, A. Development and validation of a multiple ability self-report questionnaire. J. Clin. Exp. Neuropsychol. 1994, 16, 93-104. [CrossRef] [PubMed]

154. Pincus, T.; Swearingen, C.; Wolfe, F. Toward a multidimensional health assessment questionnaire (MDHAQ): Assessment of advanced activities of daily living and psychological status in the patient-friendly health assessment questionnaire format. Arthritis Rheum. 1999, 42, 2220-2230. [CrossRef]

155. Smets, E.M.; Garssen, B.; Bonke, B.; De Haes, J.C. The multidimensional fatigue inventory (MFI) psychometric qualities of an instrument to assess fatigue. J. Psychosom. Res. 1995, 39, 315-325. [CrossRef]

156. Pincus, T.; Summey, J.A.; Soraci, S.A.; Wallston, K.A.; Hummon, N.P. Assessment of patient satisfaction in activities of daily living using a modified stanford health assessment questionnaire. Arthritis Rheum. 1983, 26, 1346-1353. [CrossRef] [PubMed]

157. Stewart, W.F.; Lipton, R.B.; Whyte, J.; Dowson, A.; Kolodner, K.; Liberman, J.N.; Sawyer, J. An international study to assess reliability of the migraine disability assessment (MIDAS) score. Neurology 1999, 53, 988-994. [CrossRef] [PubMed]

158. Sheehan, D.V.; Lecrubier, Y.; Sheehan, K.H.; Amorim, P.; Janavs, J.; Weiller, E.; Hergueta, T.; Baker, R.; Dunbar, G.C. The mini-international neuropsychiatric interview (M.I.N.I.): The development and validation of a structured diagnostic psychiatric interview for DSM-IV and ICD-10. J. Clin. Psychiat. 1998, 59, S22-S33.

159. Kuile, M.; Linssen, A.C.; Spinhoven, P. The development of the multidimensional locus of pain control questionnaire (MLPC): Factor structure, reliability, and validity. J. Psychopathol. Behav. Assess. 1993, 15, 387-404. [CrossRef]

160. Hays, R.D.; Martin, S.A.; Sesti, A.M.; Spritzer, K.L. Psychometric properties of the medical outcomes study sleep measure. Sleep Med. 2005, 6, 41-44. [CrossRef] [PubMed] 
161. Kerns, R.D.; Turk, D.C.; Rudy, T.E. The west haven-yale multidimensional pain inventory (WHYMPI). Pain 1985, 23, 345-356. [CrossRef]

162. Melzack, R. The McGill pain questionnaire: Major properties and scoring methods. Pain 1975, 1, $277-299$. [CrossRef]

163. Johnson, C. Measuring pain. Visual analog scale versus numeric pain scale: What is the difference? J. Chiropr. Med. 2005, 4, 43-44. [CrossRef]

164. Fairbank, J.C.; Pynsent, P.B. The oswestry disability index. Spine 2000, 25, 2940-2952. [CrossRef] [PubMed]

165. Riley, J.F.; Ahern, D.K.; Follick, M.J. Chronic pain and functional impairment: Assessing beliefs about their relationship. Arch. Phys. Med. Rehabil. 1988, 69, 579-582. [PubMed]

166. Laurent, J.; Catanzaro, S.J.; Joiner, T.E. Development and preliminary validation of the physiological hyperarousal scale for children. Psychol. Assess. 2004, 16, 373-380. [CrossRef] [PubMed]

167. Ruehlman, L.S.; Karoly, P.; Newton, C.; Aiken, L.S. The development and preliminary validation of the profile of chronic pain: Extended assessment battery. Pain 2005, 118, 380-389. [CrossRef] [PubMed]

168. Ruehlman, L.S.; Karoly, P.; Newton, C.; Aiken, L.S. The development and preliminary validation of a brief measure of chronic pain impact for use in the general population. Pain 2005, 113, 82-90. [CrossRef] [PubMed]

169. Reid, G.J.; Gilbert, C.A.; McGrath, P.J. The pain coping questionnaire: Preliminary validation. Pain 1998, 76, 83-96. [CrossRef]

170. Crombez, G.; Bijttebier, P.; Eccleston, C.; Mascagni, T.; Mertens, G.; Goubert, L.; Verstraeten, K. The child version of the pain catastrophizing scale (PCS-C): A preliminary validation. Pain 2003, 104, 639-646. [CrossRef]

171. Stern, B.L.; Kim, Y.; Trull, T.J.; Scarpa, A.; Pilkonis, P. Inventory of interpersonal problems personality disorder scales: Operating characteristics and confirmatory factor analysis in nonclinical samples. J. Pers. Assess. 2000, 74, 459-471. [CrossRef] [PubMed]

172. Freynhagen, R.; Baron, R.; Gockel, U.; Tölle, T.R. painDETECT: A new screening questionnaire to identify neuropathic components in patients with back pain. Curr. Med. Res. Opin. 2006, 22, 1911-1920. [CrossRef] [PubMed]

173. Tait, R.C.; Pollard, C.A.; Margolis, R.B.; Duckro, P.N.; Krause, S.J. The pain disability index: Psychometric and validity data. Arch. Phys. Med. Rehabil. 1987, 68, 438-441. [PubMed]

174. Jenkinson, C.; Fitzpatrick, R.; Peto, V.; Greenhall, R.; Hyman, N. The Parkinson's disease questionnaire (PDQ-39): Development and validation of a Parkinson's disease summary index score. Age Ageing 1997, 26, 353-357. [CrossRef] [PubMed]

175. Compton, P.; Darakjian, J.; Miotto, K. Screening for addiction in patients with chronic pain and "problematic" substance use: Evaluation of a pilot assessment tool. J. Pain Symptom Manag. 1998, 16, 355-363. [CrossRef]

176. Varni, J.W.; Seid, M.; Rode, C.A. The PedsQL: Measurement model for the pediatric quality of life inventory. Med. Care 1999, 37, 126-139. [CrossRef] [PubMed]

177. Dworkin, R.H.; Turk, D.C.; Farrar, J.T.; Haythornthwaite, J.A.; Jensen, M.P.; Katz, N.P.; Kerns, R.D.; Stucki, G.; Allen, R.R.; Bellamy, N.; et al. Core outcome measures for chronic pain clinical trials: IMMPACT recommendations. Pain 2005, 113, 9-19. [CrossRef] [PubMed]

178. Lowe, B.; Kroenke, K.; Herzog, W.; Grafe, K. Measuring depression outcome with a brief self-report instrument: Sensitivity to change of the patient health questionnaire (PHQ-9). J. Affect. Disord. 2004, 81, 61-66. [CrossRef]

179. Nicholas, M.K. The pain self-efficacy questionnaire: Taking pain into account. Eur. J. Pain 2007, 11, $153-163$. [CrossRef] [PubMed]

180. McCracken, L.M. "Attention" to pain in persons with chronic pain: A behavioral approach. Behav. Ther. 1997, 28, 271-284. [CrossRef]

181. Kopec, J.A.; Esdaile, J.M.; Abrahamowicz, M.; Abenhaim, L.; Wood-Dauphinee, S.; Lamping, D.L.; Williams, J.I. The quebec back pain disability scale. Measurement properties. Spine 1995, 20, 341-352. [CrossRef] [PubMed]

182. Fransen, J.; Langenegger, T.; Michel, B.A.; Stucki, G. Feasibility and validity of the RADAI, a self-administered rheumatoid arthritis disease activity index. Rheumatology 2000, 39, 321-327. [CrossRef] [PubMed]

183. Chorpita, B.F.; Moffitt, C.E.; Gray, J. Psychometric properties of the revised child anxiety and depression scale in a clinical sample. Behav. Res. Ther. 2005, 43, 309-322. [CrossRef] [PubMed]

184. Riddle, D.L.; Stratford, P.W. Roland-morris scale reliability. Phys. Ther. 2002, 82, 512-517. [PubMed] 
185. Derogatis, L.R.; Unger, R. Symptom Checklist-90-Revised. In The Corsini Encyclopedia of Psychology; John Wiley \& Sons, Inc.: Hoboken, NJ, USA, 2010.

186. Sheehan, K.H.; Sheehan, D.V. Assessing treatment effects in clinical trials with the discan metric of the sheehan disability scale. Int. Clin. Psychopharmacol. 2008, 23, 70-83. [CrossRef] [PubMed]

187. Ware, J.E.; Sherbourne, C.D. The MOS 36-item short-form health survey (SF-36). I. Conceptual framework and item selection. Med. Care 1992, 30, 473-483. [CrossRef] [PubMed]

188. Butler, S.F.; Budman, S.H.; Fernandez, K.; Jamison, R.N. Validation of a screener and opioid assessment measure for patients with chronic pain. Pain 2004, 112, 65-75. [CrossRef] [PubMed]

189. Hellsten, L.A.; Nigg, C.; Norman, G.; Burbank, P.; Braun, L.; Breger, R.; Coday, M.; Elliot, D.; Garber, C.; Greaney, M.; et al. Accumulation of behavioral validation evidence for physical activity stage of change. Health Psychol. 2008, 27, 43-53. [CrossRef]

190. Jensen, M.P.; Turner, J.A.; Romano, J.M.; Lawler, B.K. Relationship of pain-specific beliefs to chronic pain adjustment. Pain 1994, 57, 301-309. [CrossRef]

191. Spielberger, C.D. State-trait anxiety inventory. In The Corsini Encyclopedia of Psychology; John Wiley \& Sons, Inc.: Hoboken, NJ, USA, 2010.

192. Spielberger, C.D.; Reheiser, E.C. Assessment of emotions: Anxiety, anger, depression, and curiosity. Appl. Psychol. Health Well-Being 2009, 1, 271-302. [CrossRef]

193. Goubert, L.; Crombez, G.; van Damme, S.; Vlaeyen, J.W.; Bijttebier, P.; Roelofs, J. Confirmatory factor analysis of the Tampa Scale for Kinesiophobia: Invariant two-factor model across low back pain patients and fibromyalgia patients. Clin. J. Pain 2004, 20, 103-110. [CrossRef] [PubMed]

194. Shulman, L.M.; Gruber-Baldini, A.L.; Anderson, K.E.; Fishman, P.S.; Reich, S.G.; Weiner, W.J. The clinically important difference on the unified parkinson's disease rating scale. Arch. Neurol. 2010, 67, 64-70. [CrossRef] [PubMed]

195. Carlsson, A.M. Assessment of chronic pain. I. Aspects of the reliability and validity of the visual analogue scale. Pain 1983, 16, 87-101. [CrossRef]

196. Labus, J.S.; Bolus, R.; Chang, L.; Wiklund, I.; Naesdal, J.; Mayer, E.A.; Naliboff, B.D. The visceral sensitivity index: Development and validation of a gastrointestinal symptom-specific anxiety scale. Aliment. Pharmacol. Ther. 2004, 20, 89-97. [CrossRef] [PubMed] 